\title{
Erection of a New Onchobothriid Genus (Cestoda: Tetraphyllidea) and the Description of Five New Species from Whaler Sharks (Carcharhinidae)
}

\author{
Author(s): J. N. Caira and K. Jensen
}

Source: Journal of Parasitology, 95(4):924-940. 2009.

Published By: American Society of Parasitologists

DOI: http://dx.doi.org/10.1645/GE-1963.1

URL: http://www.bioone.org/doi/full/10.1645/GE-1963.1

BioOne (www.bioone.org) is a nonprofit, online aggregation of core research in the biological, ecological, and environmental sciences. BioOne provides a sustainable online platform for over 170 journals and books published by nonprofit societies, associations, museums, institutions, and presses.

Your use of this PDF, the BioOne Web site, and all posted and associated content indicates your acceptance of BioOne's Terms of Use, available at www.bioone.org/page/terms of use.

Usage of BioOne content is strictly limited to personal, educational, and non-commercial use. Commercial inquiries or rights and permissions requests should be directed to the individual publisher as copyright holder. 


\title{
ERECTION OF A NEW ONCHOBOTHRIID GENUS (CESTODA: TETRAPHYLLIDEA) AND THE DESCRIPTION OF FIVE NEW SPECIES FROM WHALER SHARKS (CARCHARHINIDAE)
}

\author{
J. N. Caira and K. Jensen* \\ Department of Ecology and Evolutionary Biology, 75 N. Eagleville Road, University of Connecticut, Storrs, Connecticut 06269-3043. \\ e-mail: janine.caira@uconn.edu
}

\begin{abstract}
The onchobothriid Triloculatum n. gen. is erected to house species formerly considered members of Phoreiobothrium, but that bear 3, rather than 5 or more, bothridial subloculi. The species formerly known as Phoreiobothrium triloculatum is designated as its type. This species is redescribed based on 2 syntypes and on voucher material consistent with type material taken from the type host, Carcharhinus obscurus, from the type and 1 additional locality. Examination of the cestode fauna of a diversity of carcharhinid sharks resulted in the discovery of an additional 5 new tri-subloculate species belonging to the genus. These include: Triloculatum andersonorum n. sp. from Negaprion acutidens; Triloculatum bullardi n. sp. from Carcharhinus brevipinna; Triloculatum geeceearelensis n. sp. from Carcharhinus isodon; Triloculatum jodyi n. sp. from Carcharhinus acronotus; and Triloculatum oregontwoae n. sp. from Carcharhinus plumbeus. The new species differ from one another in the number of proglottids, scolex size, number of testes, number of lateral columns of vitelline follicles, and whether they possess craspedote or acraspedote proglottids. Histology and scanning electron microscopy suggest that the new genus differs further from Phoreiobothrium in that its species possess an anterior margin of the posterior loculus that is fused to the anterior loculus, rather than free. The diagnosis of Phoreiobothrium is emended to accommodate the removal of tri-subloculate species and the new information on the condition of the locular interface, and the symmetrical ovary and vitelline follicles arranged in 2 lateral bands; each band consisting of 2 to many columns of follicles. Existing host data indicate that the new genus is restricted to only a subset of the sharks parasitized by species of Phoreiobothrium. Results from the examination of a diversity of carcharhinid species suggest that species in the new genus may have an affinity for the larger, i.e., $>200 \mathrm{~cm}$ in total length, species of Carcharhinus and Negaprion. One of the new Triloculatum species was found to attach in the crypts lying between the larger ridges found on the mucosal surface of the posterior inner region of the scroll-type spiral intestine of C. brevipinna.
\end{abstract}

In 1901, Linton provided a relatively brief description of the new species Phoreiobothrium triloculatum Linton, 1901, collected from the dusky shark, Carcharhinus obscurus (LeSueur, 1818), in Woods Hole, Massachusetts and included a figure of a bothridium. He noted that this species differed from its only other congener at that time, Phoreiobothrium lasium Linton 1889 , in its possession of bothridia, each bearing 3, rather than numerous, subloculi. Linton subsequently reported $P$. triloculatum from C. obscurus and Rhizoprionodon terraenovae (Richardson, 1836) (as Scoliodon terrae-novae [Richardson, 1836]) in Beaufort, North Carolina in 1905, and from C. obscurus and Carcharhinus plumbeus (Nardo, 1827) (as Carcharhinus milberti [Müller \& Henle, 1839]), again from Woods Hole, in 1924. References to specimens thought to be conspecific with $P$. triloculatum have since been made by multiple other authors. For example, Curtis (1911) provided detailed developmental data on material he considered to be $P$. triloculatum from "sand sharks" in Woods Hole. In an effort to clarify bothridial morphology, Perrenoud (1931) sectioned the scolex of specimens for which host and locality were not given, but which he attributed to this cestode species. Campbell (1975) emended the description of the species based on 2 specimens collected from Carcharhinus acronotus (Poey, 1860), also from Beaufort, North Carolina. Watson and Thorson (1976) reported it from the bull shark, Carcharhinus leucas (Valenciennes, 1839) from Costa Rica. Caira (1985) further emended the description of $P$. triloculatum based on her examination of Linton's syntypes and on voucher material of Linton and of MacCallum from C. obscurus and $C$. plumbeus, respectively. Most recently, Caira et al. (2001) included a species of Phoreiobothrium bearing 3 subloculi (as Phoreiobo-

Received 15 November 2008; revised 1 February 2009; accepted 19 February 2009.

* Department of Ecology and Evolutionary Biology, and the Natural History Museum and Biodiversity Research Center, University of Kansas, 1200 Sunnyside Avenue, Lawrence, Kansas 66045.

DOI: 10.1645/GE-1963.1 thrium n. sp. 3), taken from C. leucas in the Gulf of California, in their morphological analysis of the phylogenetic relationships among tetraphyllidean genera. The latter authors were the first to question the conspecificity of all Phoreiobothrium specimens bearing 3 subloculi.

Recent efforts to collect cestodes from carcharhinid sharks, globally, confirms that the diversity of Phoreiobothrium specimens bearing 3 subloculi extends well beyond a single species. Further investigation of this material suggests that the erection of a new genus to house these tri-subloculate species is in order. This new genus is established below with the species formerly known as $P$. triloculatum as its type. The type species is redescribed based on type and newly collected voucher material from the type host, $C$. obscurus, in order to rectify the fact that the current concept of this species is based on data generated from a diversity of trisubloculate specimens that are considered not conspecific. In addition, 5 new species, 1 each from Negaprion acutidens (Rüppell, 1837), C. acronotus, Carcharhinus brevipinna (Müller \& Henle, 1839), Carcharhinus isodon (Valenciennes, 1839), and $C$. plumbeus, are described.

\section{MATERIALS AND METHODS}

Hosts examined represented 5 species of carcharhinid sharks and consisted of: 1 male $(80 \mathrm{~cm}$ total length [TL]) and 1 female $(89 \mathrm{~cm} \mathrm{TL})$ specimen of Negaprion acutidens, collected with stationary nets from the Gulf of Carpentaria near Weipa $\left(12^{\circ} 39^{\prime} 60.00^{\prime \prime} \mathrm{S}, 141^{\circ} 52^{\prime} 0.00^{\prime \prime} \mathrm{E}\right)$, Queensland, Australia in May 2004 and June 2003, respectively; 1 specimen each of C. acronotus and C. brevipinna (sex and TL unknown), collected with hook and line near oil rig MO-990 $\left(29^{\circ} 58^{\prime} 58.20^{\prime \prime} \mathrm{N}, 88^{\circ} 36^{\prime} 16.80^{\prime \prime} \mathrm{W}\right)$, Louisiana, Gulf of Mexico, in June 2006; 1 male specimen (174 cm TL) of C. brevipinna, collected with hook and line off the southwest end of Horn Island $\left(30^{\circ} 13^{\prime} 20.72^{\prime \prime} \mathrm{N}, 88^{\circ} 47^{\prime} 13.64^{\prime \prime} \mathrm{W}\right)$, Mississippi, Gulf of Mexico in October 2006; 1 male specimen $(82 \mathrm{~cm} \mathrm{TL})$ of $C$. isodon, collected with a gill net off Round Island $\left(30^{\circ} 17^{\prime} 42.45^{\prime \prime} \mathrm{N}, 88^{\circ} 35^{\prime} 11.55^{\prime \prime} \mathrm{W}\right)$, Mississippi, Gulf of Mexico in June 2005; 2 male specimens $(111 \mathrm{~cm}$ and $105 \mathrm{~cm}$ TL) of C. isodon, collected with a gill net off Indian Pass $\left(29^{\circ} 40^{\prime} 8.05^{\prime \prime} \mathrm{N}\right.$, $\left.85^{\circ} 13^{\prime} 30.17^{\prime \prime} \mathrm{W}\right)$, Florida, Gulf of Mexico in May 2007; 1 male specimen of C. plumbeus (157 cm fork length), caught by long-line off the Alabama- 
Florida state line $\left(30^{\circ} 07^{\prime} 60.00^{\prime \prime} \mathrm{N}, 87^{\circ} 27^{\prime} 0.00^{\prime \prime} \mathrm{W}\right)$ in August 1995 ; and 1 male specimen of $C$. plumbeus (unknown TL) caught by long-line off Florida $\left(30^{\circ} 21^{\prime} 07.80^{\prime \prime} \mathrm{N}, 86^{\circ} 43^{\prime} 53.40^{\prime \prime} \mathrm{W}\right)$ in August 1996.

Spiral intestines were removed from each host and opened with a longitudinal incision. They were fixed in $10 \%$ formalin, buffered with seawater, and subsequently transferred to $70 \%$ ethanol for storage. Cestodes were removed from the spiral intestines upon return to the laboratory.

Cestodes prepared as whole-mounts were hydrated, stained in Delafield's haematoxylin, dehydrated in a graded ethanol series, cleared in methyl salicylate, and mounted on glass slides in Canada balsam. Measurements were made using a Leica DFC320 digital camera mounted on a Zeiss Axioskop 2 using the image analysis software OpenLab Demo 4.0.4 (Improvision Inc., Waltham, Massachusetts). Measurements are in micrometers unless otherwise indicated, and are given in the text as ranges; corresponding means, standard deviations, number of specimens examined, and number of measurements made are given in Table I. Hook measurements taken follow Caira et al. (2005).

Histological sections were prepared from the terminal proglottids of one specimen each of the new species from $C$. brevipinna and $C$. isodon. In addition, in situ cross and longitudinal sections were prepared of the scolex of the new species found attached to the spiral intestine of $C$. brevipinna. In both cases, the remainder of the worm was prepared as a whole-mount, as described above. Sections were prepared as follows: terminal proglottids or tissue were embedded in paraffin and sectioned at 5-8 $\mu \mathrm{m}$ intervals using an Olympus CUT4060 retracting rotary microtome. The sections were then placed on glass slides, flooded with $2.5 \%$ sodium silicate, and allowed to dry on a slide warmer. Sections were subsequently stained with Delafield's haematoxylin and eosin, cleared in xylene, and mounted with coverslips in Canada balsam.

Scolices of 1-2 specimens of each of the 6 species treated here were prepared for examination with scanning electron microscopy (SEM), as follows. They were hydrated, transferred to $1.5 \%$ osmium tetroxide overnight, dehydrated in a graded ethanol series, and placed in hexamethyldisilizane (HMDS, Ted Pella, Inc., Redding, California) in a fume hood for $15 \mathrm{~min}$. They were allowed to air dry and were subsequently mounted on carbon tape and grounded with carbon paint on aluminum stubs. Specimens were sputter-coated with approx. $40 \mathrm{~nm}$ of goldpalladium and examined with a LEO/Zeiss DSM 982 Gemini field emission scanning electron microscope (FESEM) or with a LEO/Zeiss 1550 FESEM.

Museum abbreviations used are as follows: LRP, Lawrence R. Penner Parasitology Collection, University of Connecticut, Storrs, Connecticut; QM, Queensland Museum, Brisbane, Australia; USNPC, United States National Parasite Collection, Beltsville, Maryland. Shark taxonomy and common names follow Compagno (1984).

\section{DESCRIPTION}

\section{Triloculatum $\mathbf{n}$. gen.}

Diagnosis: Tetraphyllidea, sensu Euzet (1994); Onchobothriidae Braun, 1900, sensu Euzet (1994). Scolex with 4 bothridia; each with anterior muscular pad in form of sucker and 1 pair of hooks with 3 unequal prongs and talon; basal prong of medial hook conspicuously longer than basal prong of lateral hook. Bothridia each consisting of 2 subequal loculi. Anterior loculus simple, longer than posterior loculus. Posterior loculus divided into 3 subloculi. Anterior margin of posterior loculus fused to proximal surface of posterior margin of anterior loculus. Cephalic peduncle present, covered with large, blade-like spinitriches, posterior margin of cephalic peduncle inconspicuous. Strobila acraspedote or craspedote, euapolytic. Gential pores lateral, irregularly alternating. Testes numerous; postvaginal testes present on poral side. Ovary posterior, symmetrical, H-shaped in frontal view, bi-lobed in cross section. Vagina muscular, anterior to cirrus sac. Vitelline follicles in 2 lateral bands; each band consisting of 2 to many columns of follicles. Uterus sacshaped, medioventral. In spiral intestine of Carcharhinidae. Cosmopoli$\tan$.

\section{Taxonomic summary}

Type species: Triloculatum triloculatum (Linton, 1901) n. comb. Etymology: This genus is named for its type species.

\section{Remarks}

The new genus is erected to accommodate onchobothriid species with tri-pronged hooks that possess 3 , rather than 5 or more, bothridial subloculi. It can readily be distinguished from all other onchobothriid genera, except Phoreiobothrium, in that its species possess hooks that are tri-pronged (rather than uni- or bi-pronged). Beyond sublocular number, SEM and histology reveal an additional pronounced difference in scolex morphology between the 2 genera. Whereas in species of Phoreiobothrium there is a clear distinction between the posterior margin of the anterior loculus and the anterior margin of the posterior loculus, i.e., the subloculi, because both margins are free (Figs. 1, 2; Caira et al, 1995, 2005), this is not the case in members of the new genus. In species of the new genus, the anterior margin of the posterior loculus is fused to the proximal side of the anterior loculus close to its posterior margin (Figs. 3, 4). Thus, although the posterior margin of the anterior loculus is free, the anterior margin of the posterior loculus is not. Curiously, members of the new genus also lack the suite of conspicuous papillae found along the posterior margin of the anterior loculus seen in many species of Phoreiobothrium.

We propose that the most recent diagnosis of Phoreiobothrium (see Caira et al., 2005) be emended to read as follows, not only to accommodate the transfer of species bearing 3 subloculi to Triloculatum n. gen., but also to clarify the condition of the anterior margin of the posterior loculus and to add details on the conditions of the ovary and vitelline follicles.

\section{Phoreiobothrium Linton, 1889 emend.}

Diagnosis: Tetraphyllidea, sensu Euzet (1994); Onchobothriidae Braun, 1900 sensu Euzet (1994). Scolex with 4 bothridia each with anterior muscular pad in form of sucker and 1 pair of hollow hooks with 3 (or occasionally 2) unequal prongs and talon. Bothridia each consisting of 2 subequal loculi. Anterior loculus simple, longer than posterior loculus. Posterior loculus divided into 5 or more subloculi. Anterior margin of posterior loculus free. Cephalic peduncle present with large, blade-like spinitriches, posterior margin of cephalic peduncle inconspicuous. Strobila acraspedote, euapolytic. Genital pores lateral, irregularly alternating. Testes numerous; postvaginal testes present on poral side. Ovary posterior, symmetrical, H-shaped in frontal view, bi-lobed in cross section. Vagina muscular, anterior to cirrus sac. Vitelline follicles in 2 lateral bands; each band consisting of 2 to many columns of follicles. Uterus sacshaped, medioventral. In spiral intestine of Carcharhinidae and Sphyrnidae. Cosmopolitan. Type species: Phoreiobothrium lasium Linton, 1889.

\section{REDESCRIPTION}

\section{Triloculatum triloculatum (Linton, 1901) n. comb.} (Figs. 5, 11-13, 17-21)

Redescription (based on 2 syntype and 7 voucher specimens: 4 whole mounts of mature worms [3 incomplete], 3 whole mounts of immature worms [some incomplete], and 2 scolices prepared for SEM): Worms $18.8 \mathrm{~mm}$ long, euapolytic, greatest width at terminal proglottid, 700 wide; proglottids $54+$ per worm, acraspedote. Scolex consisting of scolex proper and cephalic peduncle. Scolex proper 534-667 long by 606-738 wide, with 4 bothridia. Bothridia 524-664 long by $263-325$ wide, each with anterior muscular pad in form of sucker, and 2 subequal loculi divided by horizontal septum. Anterior loculus 312-464 long, bearing 1 pair of hooks with 3 unequal prongs and talon; posterior loculus shorter than anterior loculus, divided into 3 subloculi (Fig. 18); subloculi approximately equal in width, 82-115 wide. Hooks tri-pronged, smooth, hollow; lateral hook lengths: A 101-128, B 103-123, C 89-123, D 114-148, E 14-23, F 35-47; medial hook lengths: A' 112-131, B' 114-136, C' 91-123, D' 117-154, E' 26-43, $\mathrm{F}^{\prime}$ 40-50; internal hook channel continuous between prongs, extending into talon; lateral and medial hooks approximately equal in length. Cephalic peduncle with inconspicuous posterior limit.

Distal and proximal bothridial surfaces, apex of scolex, and scolex proper between bothridia covered with short filitriches only (Figs. 19-20). Cephalic peduncle covered with large, blade-like spinitriches and long filitriches (Fig. 21).

Immature proglottids 54+ in number, most wider than long, posteriormost immature proglottid $580-1,112$ long by $308-615$ wide; mature proglottids 3 in number, terminal proglottid in complete worm 2,243 long 
TABLE I. Measurements of species of Triloculatum n. gen.*

\begin{tabular}{|c|c|c|c|c|c|c|}
\hline & $\begin{array}{l}\text { T. triloculatum } \\
\text { (Linton, 1901) } \\
\text { n. comb. }\end{array}$ & $\begin{array}{l}\text { T. andersonorum } \\
\text { n. sp. }\end{array}$ & $\begin{array}{l}\text { T. bullardi } \\
\text { n. sp. }\end{array}$ & $\begin{array}{l}\text { T. geeceearelensis } \\
\text { n. sp. }\end{array}$ & $\begin{array}{l}\text { T. jodyi } \\
\text { n. sp. }\end{array}$ & $\begin{array}{l}\text { T. oregontwoae } \\
\text { n. sp. }\end{array}$ \\
\hline Total length & $18.8 \mathrm{~mm}^{\dagger}$ & $8.4 \mathrm{~mm} \pm 0.4 ; 5$ & $17.1 \mathrm{~mm} \pm 3.7 ; 17$ & $15 \mathrm{~mm} \pm 2.1 ; 11$ & $9.6 \mathrm{~mm} \pm 1.8 ; 3$ & $12.4 \mathrm{~mm} \pm 3.4 ; 8$ \\
\hline Greatest width & $700 \dagger$ & $335 \pm 22 ; 7$ & $950 \pm 105 ; 17$ & $825 \pm 102 ; 11$ & $485 \pm 30 ; 3$ & $633 \pm 108 ; 10$ \\
\hline No. of proglottids & $54+$ & $85 \pm 8 ; 5$ & $78 \pm 9 ; 17$ & $54 \pm 10 ; 11$ & $48 \pm 3 ; 3$ & $67 \pm 14 ; 9$ \\
\hline Scolex proper length & $620 \pm 47 ; 7$ & $374 \pm 47 ; 5$ & $696 \pm 49 ; 15$ & $612 \pm 52 ; 11$ & $539 \pm 55 ; 3$ & $757 \pm 100 ; 9$ \\
\hline Scolex proper width & $649 \pm 47 ; 6$ & $484 \pm 26 ; 5$ & $680 \pm 33 ; 15$ & $626 \pm 61 ; 11$ & $505 \pm 22 ; 3$ & $758 \pm 69 ; 9$ \\
\hline Bothridial length & $595 \pm 48 ; 7 ; 14$ & $365 \pm 48 ; 5 ; 10$ & $660 \pm 53 ; 15 ; 28$ & $596 \pm 49 ; 10 ; 21$ & $504 \pm 49 ; 3 ; 6$ & $718 \pm 82 ; 9 ; 18$ \\
\hline Bothridial width & $295 \pm 21 ; 11$ & $269 \pm 25 ; 5 ; 10$ & $317 \pm 15 ; 17 ; 27$ & $290 \pm 22 ; 10 ; 17$ & $249 \pm 25 ; 3 ; 6$ & $352 \pm 32 ; 9 ; 17$ \\
\hline \multicolumn{7}{|l|}{ Anterior loculus } \\
\hline length & $372 \pm 47 ; 7 ; 14$ & $202 \pm 36 ; 5 ; 9$ & $461 \pm 41 ; 17 ; 28$ & $427 \pm 61 ; 11 ; 19$ & $371 \pm 31 ; 2 ; 4$ & $504 \pm 39 ; 9 ; 15$ \\
\hline Subloculus width & $100 \pm 10 ; 7 ; 18$ & $94 \pm 12 ; 5 ; 15$ & $103 \pm 11 ; 17 ; 50$ & $94 \pm 9 ; 11 ; 29$ & $92 \pm 12 ; 3 ; 9$ & $119 \pm 13 ; 9 ; 18$ \\
\hline \multicolumn{7}{|l|}{ Lateral hook } \\
\hline A & $118 \pm 11 ; 6 ; 7$ & $112 \pm 5 ; 3$ & $107 \pm 15 ; 13$ & $112 \pm 18 ; 9 ; 10$ & $99 \pm 19 ; 3$ & $144 \pm 4 ; 7$ \\
\hline $\mathrm{B}$ & $114 \pm 8 ; 6 ; 7$ & $134 \pm 14 ; 3$ & $111 \pm 8 ; 12$ & $103 \pm 10 ; 8 ; 9$ & $96 \pm 9 ; 3$ & $129 \pm 6 ; 7$ \\
\hline $\mathrm{C}$ & $105 \pm 12 ; 6 ; 7$ & $124 \pm 5 ; 4$ & $112 \pm 6 ; 13$ & $102 \pm 9 ; 9 ; 11$ & $105 \pm 1 ; 3$ & $123 \pm 5 ; 7$ \\
\hline $\mathrm{D}$ & $130 \pm 13 ; 5 ; 6$ & $134 \pm 5 ; 2$ & $126 \pm 12 ; 12$ & $134 \pm 13 ; 6 ; 7$ & $123 \pm 11 ; 3$ & $149 \pm 11 ; 7$ \\
\hline $\mathrm{E}$ & $21 \pm 5 ; 5 ; 6$ & $43 \pm 6 ; 5 ; 6$ & $24 \pm 3 ; 14$ & $19 \pm 3 ; 9 ; 11$ & $25 \pm 2 ; 2$ & $23 \pm 2 ; 7$ \\
\hline $\mathrm{F}$ & $42 \pm 4 ; 5 ; 6$ & $62 \pm 4 ; 5$ & $45 \pm 4 ; 11$ & $42 \pm 6 ; 10 ; 13$ & $45 \pm 8 ; 3$ & $44 \pm 65 ; 7$ \\
\hline \multicolumn{7}{|l|}{ Medial hook } \\
\hline $\mathrm{A}^{\prime}$ & $122 \pm 7 ; 6 ; 7$ & $104 \pm 11 ; 5 ; 6$ & $111 \pm 13 ; 15 ; 19$ & $116 \pm 17 ; 9 ; 10$ & $98 \pm 9 ; 3 ; 4$ & $135 \pm 10 ; 8 ; 10$ \\
\hline $\mathrm{B}^{\prime}$ & $126 \pm 8 ; 6 ; 7$ & $128 \pm 14 ; 5 ; 6$ & $123 \pm 8 ; 15 ; 19$ & $118 \pm 14 ; 8 ; 9$ & $107 \pm 7 ; 3 ; 4$ & $138 \pm 8 ; 8 ; 10$ \\
\hline $\mathrm{C}^{\prime}$ & $108 \pm 11 ; 6 ; 7$ & $123 \pm 4 ; 5 ; 6$ & $115 \pm 5 ; 16 ; 20$ & $104 \pm 6 ; 10 ; 12$ & $98 \pm 10 ; 3 ; 4$ & $122 \pm 7 ; 8 ; 10$ \\
\hline $\mathrm{D}^{\prime}$ & $136 \pm 13 ; 6 ; 7$ & $142 \pm 15 ; 6$ & $143 \pm 10 ; 15 ; 19$ & $141 \pm 13 ; 8 ; 9$ & $134 \pm 5 ; 3 ; 4$ & $155 \pm 13 ; 8 ; 10$ \\
\hline$E^{\prime}$ & $35 \pm 7 ; 6 ; 7$ & $55 \pm 6 ; 6$ & $46 \pm 5 ; 15 ; 19$ & $42 \pm 5 ; 9 ; 11$ & $43 \pm 2 ; 3 ; 4$ & $47 \pm 4 ; 8 ; 10$ \\
\hline $\mathrm{F}^{\prime}$ & $45 \pm 4 ; 4 ; 5$ & $69 \pm 6 ; 6$ & $45 \pm 7 ; 14 ; 17$ & $41 \pm 3 ; 5 ; 6$ & $38 \pm 4 ; 3 ; 4$ & $44 \pm 6 ; 8 ; 10$ \\
\hline \multicolumn{7}{|l|}{ No. of immature } \\
\hline proglottids & $54+$ & $84 \pm 8 ; 5$ & $74 \pm 9 ; 17$ & $51 \pm 9 ; 11$ & $46 \pm 4 ; 3$ & $67 \pm 13 ; 9$ \\
\hline \multicolumn{7}{|l|}{ Immature proglottid } \\
\hline length & $753 \pm 247 ; 4$ & $566 \pm 74 ; 7$ & $716 \pm 106 ; 17$ & $614 \pm 110 ; 11$ & $793 \pm 293 ; 3$ & $670 \pm 97 ; 3$ \\
\hline \multicolumn{7}{|l|}{ Immature proglottid } \\
\hline \multicolumn{7}{|l|}{ No. of mature } \\
\hline \multicolumn{7}{|l|}{ Mature proglottid } \\
\hline & $550 \pm 55 ; 3$ \\
\hline No. of testes & $142 \pm 17 ; 4 ; 7$ & $112 \pm 15 ; 7$ & $176 \pm 19 ; 17 ; 23$ & $149 \pm 15 ; 11 ; 21$ & $103 \pm 23 ; 3 ; 5$ & $160 \pm 15 ; 9 ; 12$ \\
\hline \multicolumn{7}{|l|}{ No. of postvaginal } \\
\hline Testis length & $41 \pm 12 ; 4 ; 12$ & $19 \pm 4 ; 7 ; 21$ & $47 \pm 10 ; 17 ; 51$ & $47 \pm 6 ; 11 ; 33$ & $31 \pm 6 ; 3 ; 9$ & $29 \pm 5 ; 3 ; 9$ \\
\hline Testis width & $45 \pm 15 ; 4 ; 12$ & $23 \pm 6 ; 7 ; 21$ & $63 \pm 9 ; 17 ; 51$ & $60 \pm 6 ; 11 ; 33$ & $52 \pm 8 ; 3 ; 9$ & $46 \pm 2 ; 3 ; 9$ \\
\hline Cirrus sac length & $171 \pm 40 ; 4$ & $94 \pm 9 ; 6$ & $257 \pm 33 ; 17$ & $227 \pm 26 ; 11 ; 13$ & $180 \pm 9 ; 3$ & $190 \pm 15 ; 3$ \\
\hline Cirrus sac width & $77 \pm 25 ; 4$ & $51 \pm 13 ; 7$ & $114 \pm 17 ; 17$ & $135 \pm 20 ; 11 ; 13$ & $65 \pm 21 ; 3$ & $61 \pm 17 ; 3$ \\
\hline Genital pore positiont & $46 \pm 4 ; 4$ & $52 \pm 4 ; 7$ & $53 \pm 5 ; 17$ & $52 \pm 3 ; 11$ & $53 \pm 2 ; 3$ & $53 \pm 9 ; 3$ \\
\hline Ovary length & $361 \pm 230 ; 4$ & $235 \pm 42 ; 6$ & $577 \pm 136 ; 17$ & $444 \pm 98 ; 11 ; 13$ & $338 \pm 115 ; 3$ & $290 \pm 113 ; 3$ \\
\hline Ovary width & $344 \pm 133 ; 4$ & $157 \pm 58 ; 6$ & $423 \pm 66 ; 15$ & $475 \pm 104 ; 11 ; 13$ & $281 \pm 63 ; 3$ & $319 \pm 53 ; 3$ \\
\hline Vitelline follicle length & $19 \pm 5 ; 4 ; 12$ & $10 \pm 2 ; 7 ; 18$ & $24 \pm 6 ; 17 ; 51$ & $26 \pm 6 ; 11 ; 33$ & $17 \pm 2 ; 3 ; 9$ & $17 \pm 4 ; 3 ; 9$ \\
\hline Vitelline follicle width & $31 \pm 11 ; 4 ; 12$ & $13 \pm 3 ; 7 ; 18$ & $39 \pm 9 ; 17 ; 51$ & $44 \pm 9 ; 11 ; 33$ & $33 \pm 4 ; 3 ; 9$ & $34 \pm 8 ; 3 ; 9$ \\
\hline
\end{tabular}

by 702 wide; gravid proglottids not observed. Testes oval, 121-162 in number, of these 15-23 postvaginal, 28-63 long by 26-74 wide, in approx. 7-9 columns anterior to cirrus sac, 1 layer deep in cross section. Vas deferens minimal, coiling anteriorly and laterally to cirrus sac, entering cirrus sac at its distal end. Cirrus sac oval, 134-227 long by 56-112 wide, not reaching midline of proglottid, containing coiled cirrus; cirrus covered with spinitriches. Genital pores marginal, irregularly alternating, $41-50 \%$ of proglottid length from posterior end in terminal proglottids. Vagina sinuous in proximal region, extending along midline of proglottid from ootype region to anterior margin of cirrus sac, then laterally along anterior margin of cirrus sac, opening into common genital atrium anterior to cirrus sac; vaginal sphincter not observed; seminal receptacle present. 


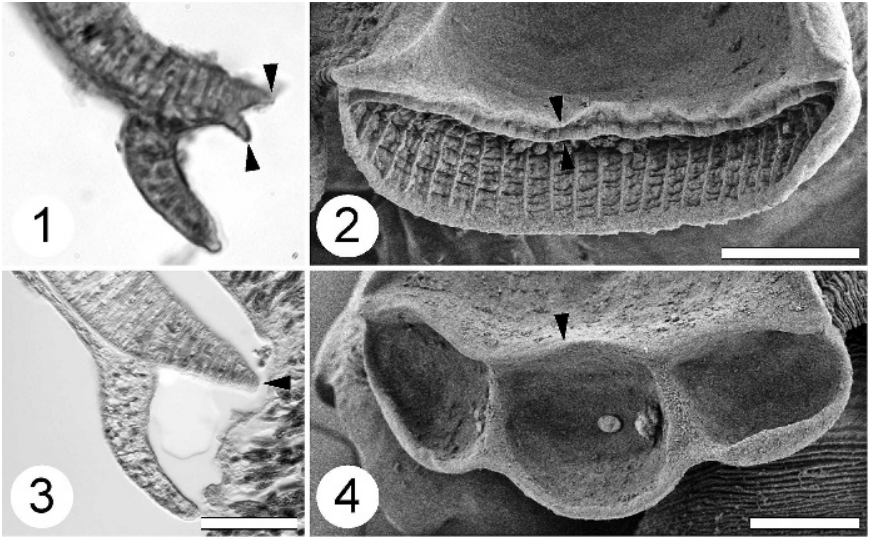

FIGURES 1-4. Detail of bothridial loculi of Phoreiobothrium and Triloculatum. (1) Longitudinal section of interface between anterior and posterior loculi of Phoreiobothrium manirei Caira, Healy, and Swanson, 1996 (LRP No. 2618). (2) Scanning electron micrograph of interface between anterior and posterior loculi of Phoreiobothrium blissorum Caira, Richmond, and Swanson, 2005. Arrowheads indicate posterior margin of anterior loculus (upper arrowhead) and anterior region of posterior loculus (lower arrowhead) in Figures 1, 2. (3) Longitudinal section through interface between anterior and posterior loculi in Triloculatum bullardi n. sp. (4) Scanning electron micrograph of interface between anterior and posterior loculi of Triloculatum andersonorum $\mathrm{n}$. $\mathrm{sp}$. Arrowheads indicate free anterior margin of posterior loculus in Figures 3, 4.

Ovary near posterior margin of proglottid, $\mathrm{H}$-shaped in frontal view, 230 704 long by $202-508$ wide, bi-lobed in cross section, lobulated; ovarian isthmus slightly posterior to middle of ovary. Mehlis' gland posterior to ovarian isthmus. Vitellarium follicular, in 2 lateral bands; each band consisting of 2 columns of follicles, extending almost entire length of proglottid, interrupted by vagina and cirrus sac, uninterrupted by ovary; vitelline follicles 13-27 long by 16-45 wide. Uterus ventral, extending anteriorly from level of ovarian bridge, stopping 4 testes-lengths short of anterior margin of field of testes. Excretory ducts 4, lateral. Eggs not observed.

\section{Taxonomic summary}

Type host: Carcharhinus obscurus (Lesueur, 1818), dusky shark (Elasmobranchii; Carcharhinidae).

Additional hosts: None.

Type locality: Off Woods Hole $\left(41^{\circ} 31^{\prime} 30.19^{\prime \prime} \mathrm{N}, 70^{\circ} 40^{\prime} 21.41^{\prime \prime} \mathrm{W}\right)$, Massachusetts.

Additional localities: Off Beaufort $\left(34^{\circ} 42^{\prime} 57.02^{\prime \prime} \mathrm{N}, 76^{\circ} 39^{\prime} 37.69^{\prime \prime} \mathrm{W}\right)$, North Carolina.

Site of infection: Spiral intestine.

Specimens included in redescription: USNPC No. 6644 (2 syntypes) and USNPC No. 35875 (1 topotype) ex C. obscurus, Woods Hole, Massachusetts; USNPC No. 1272 (2 vouchers) and LRP Nos. 4303-4306 (4 vouchers including strobilar vouchers for scolices prepared for SEM) collected by E. Linton from C. obscurus in Beaufort, North Carolina, from Personal Collection of N. Riser; 2 scolices prepared for SEM collected by E. Linton from C. obscurus in Beaufort, North Carolina, from Personal Collection of N. Riser, retained in junior author's personal collection.

Additional material examined: USNPC Nos. 7686 and 35804 (vouchers) ex C. plumbeus (as C. milberti), Woods Hole, Massachusetts; USNPC No. 71472 (voucher) ex C. leucas, Rio Colorado, Barro del Colorado, Costa Rica.

\section{Remarks}

The redescription presented here is based solely on type and voucher material taken from the type host, $C$. obscurus, because specimens from other hosts do not appear to be conspecific with $T$. triloculatum. Thus, the redescription excludes the information presented by Linton (1924;
USNPC No. 7686) and Caira (1985) for material from $C$. plumbeus, by Linton (1905) for material from R. terraenovae, and by Campbell (1975) for material from $C$. acronotus.

Linton's (1901) description of T. triloculatum was based on 26 specimens collected from 3 host individuals of $C$. obscurus between August 1899 and July 1900. It appears that few specimens remain of the syntype series: only the 2 syntypes prepared as whole-mounts for this study and a vial of unmounted material consisting of an incomplete worm, a detached scolex, and several strobilar fragments. Linton presented few measurements of this species in the original description, and ranges were not given. The measurements that are directly comparable between Linton's original description and the redescription presented here suggest that in general, his specimens of $T$. triloculatum were slightly larger than those included in the redescription presented here; for example, in the total length ( $25 \mathrm{~mm}$ vs. $18.8 \mathrm{~mm}$ ), scolex proper length (710 vs. 534-667), scolex width (760 vs. $606-738)$, terminal proglottid length $(3,000$ vs. 2,243$)$ and in the width (780 vs. 702$)$.

In addition, examination of Watson and Thorson's specimen of " $P$. triloculatum" (USNPC No. 71472) revealed it to possess approx. 13, rather than 3, subloculi. Thus, the report of Watson and Thorson (1976) of T. triloculatum (as P. triloculatum) from C. leucas in Guatemala and Costa Rica, and all subsequent references to that report (e.g., RodriguezOrtiz et al., 2004), should be removed from consideration in both the treatments of hosts and in the geographic distributions of T. triloculatum (Linton, 1901) n. comb. The redescription also excludes information provided by Perrenoud (1931) because the origin of his material was not given, and we were unable to locate any of his specimens for study.

\section{DESCRIPTIONS}

\section{Triloculatum andersonorum n. sp.}

(Figs. 6, 14-16, 22-26)

Description (based on 7 specimens: 5 whole mounts of mature worms and 2 scolices prepared for SEM and their strobilar vouchers): Worms 7.85$8.81 \mathrm{~mm}$ long, euapolytic, greatest width at proglottid 10-18 from posterior end, 306-367 wide; proglottids 78-99 per worm, craspedote. Scolex consisting of scolex proper and cephalic peduncle. Scolex proper $340-448$ long by 454-519 wide, with 4 bothridia. Bothridia 304-446 long by 236-307 wide, each with anterior muscular pad in form of sucker, and 2 subequal loculi divided by horizontal septum. Anterior loculus 162-264 long, bearing 1 pair of hooks with 3 unequal prongs and talon; posterior loculus shorter than anterior loculus, divided into 3 subloculi (Fig. 23); subloculi 77-123 wide, middle loculus usually slightly larger than lateral loculi. Hooks tri-pronged, smooth, hollow; lateral hook lengths: A 107 117, B 119-146, C 119-130, D 130-137, E 35-49, F 56-68; medial hook lengths: A' 89-117, B' 111-146, C' 119-129, D' 124-164, E' 47-63, F' 64 79; internal hook channel continuous between prongs, extending into talon; lateral and medial hooks approximately equal in length. Cephalic peduncle with inconspicuous posterior limit.

Distal and proximal bothridial surfaces, apex of scolex, and scolex proper between bothridia covered with short filitriches only (Figs. 24-25). Cephalic peduncle covered with large, blade-like spinitriches and long filitriches (Fig. 26).

Immature proglottids $77-98$ in number, initially wider than long, posteriormost immature proglottid longer than wide, 424-650 long by 253-321 wide; mature proglottids 1 in number, 573-914 long by 243-366 wide; gravid proglottids not observed. Testes oval, $82-122$ in number, of these 9-20 postvaginal, 12-26 long by 14-35 wide, in approx. 5-7 irregular columns anterior to cirrus sac, 1 layer deep in cross section. Vas deferens minimal, coiling anteriorly to cirrus sac, entering cirrus sac at its distal end. Cirrus sac bent anteriorly, 83-109 long by 39-77 wide, barely reaching midline of proglottid, containing coiled cirrus; cirrus covered with spinitriches. Genital pores marginal, irregularly alternating, 46-57\% of proglottid length from posterior end in terminal proglottids. Vagina weakly sinuous, extending along midline of proglottid from ootype region to anterior margin of cirrus sac, then laterally along anterior margin of cirrus sac, opening into common genital atrium anterior to cirrus sac; vaginal sphincter not observed; seminal receptacle not observed. Ovary near posterior margin of proglottid, $\mathrm{H}$-shaped in frontal view, 179-278 long by 117-272 wide, bi-lobed in cross section, lobulated; ovarian isthmus slightly anterior to middle of ovary. Mehlis' gland posterior to ovarian isthmus. Vitellarium follicular, in 2 lateral bands; each band 

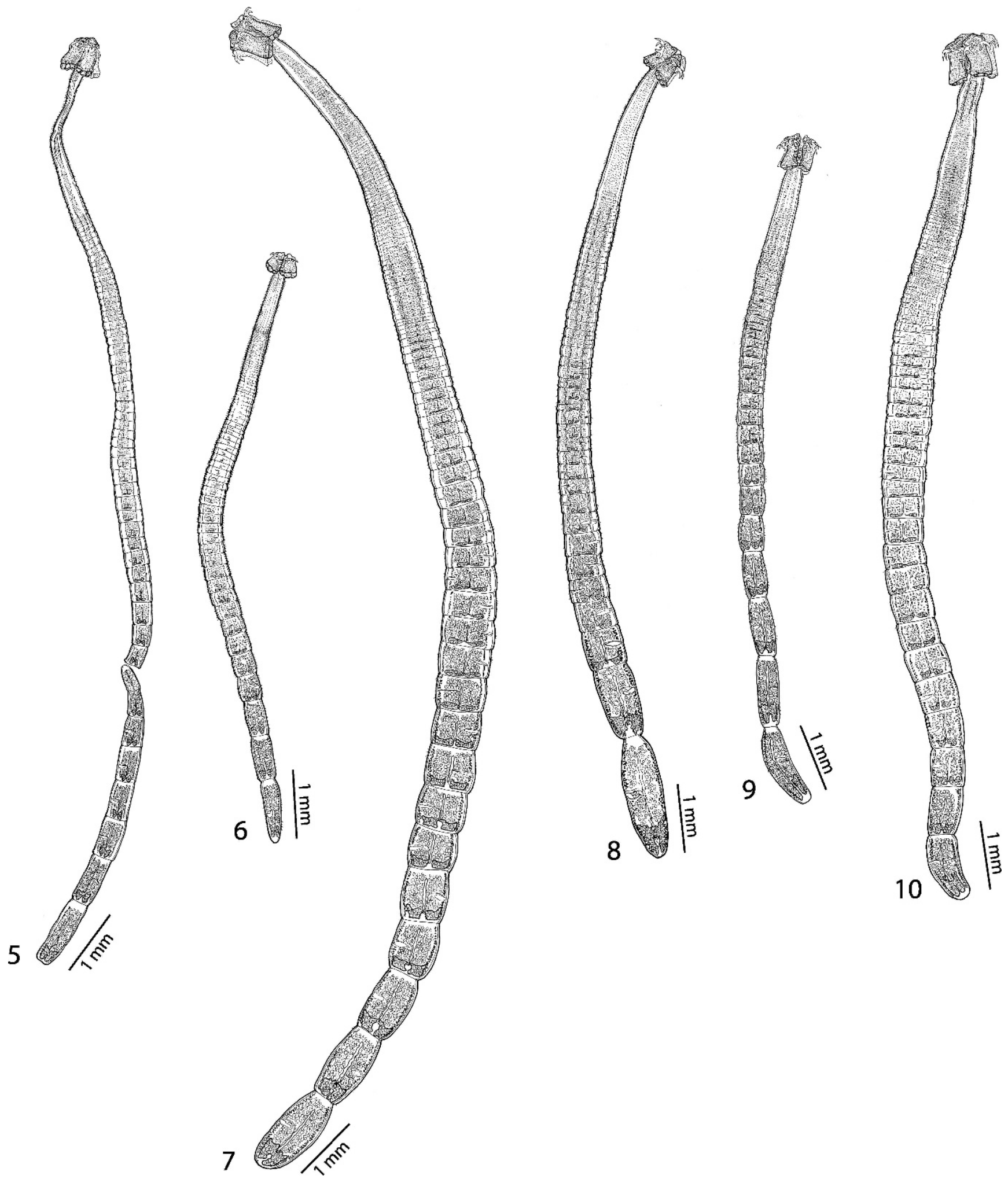
Carcharhinus obscurus. (6) Triloculatum andersonorum n. sp. ex Negaprion acutidens. (7) Triloculatum bullardi n. sp. ex. Carcharhinus brevipinna. (8) Triloculatum geeceearelensis n. sp. ex Carcharhinus isodon. (9) Triloculatum jodyi $\mathrm{n}$. sp. ex Carcharhinus acronotus. (10) Triloculatum oregontwoae n. sp. ex Carcharhinus plumbeus. 

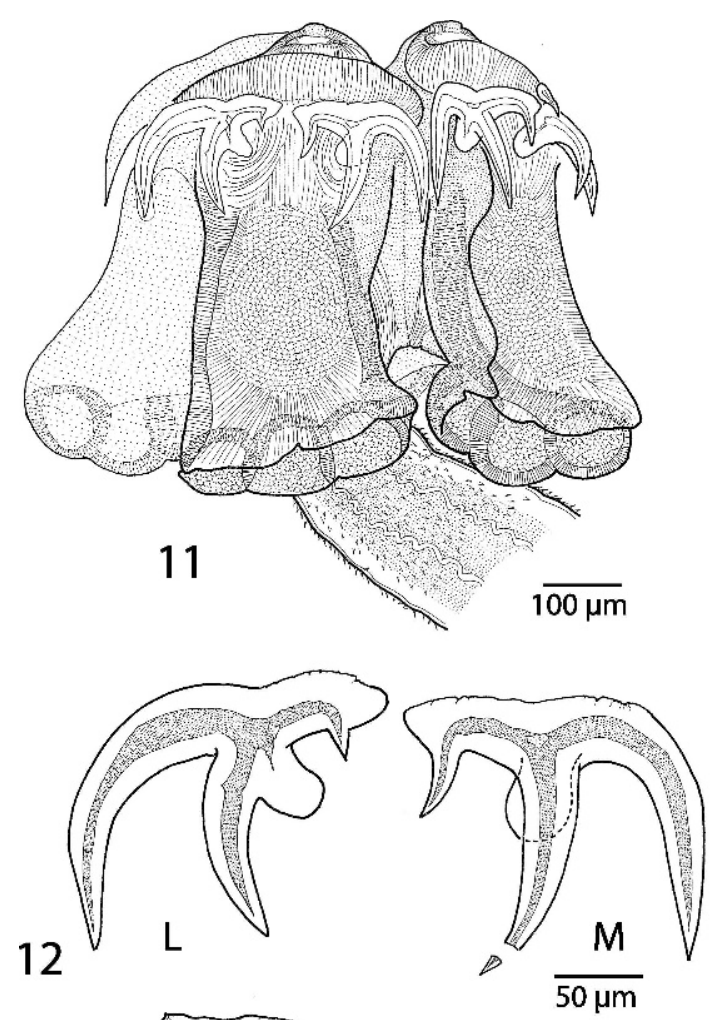

12

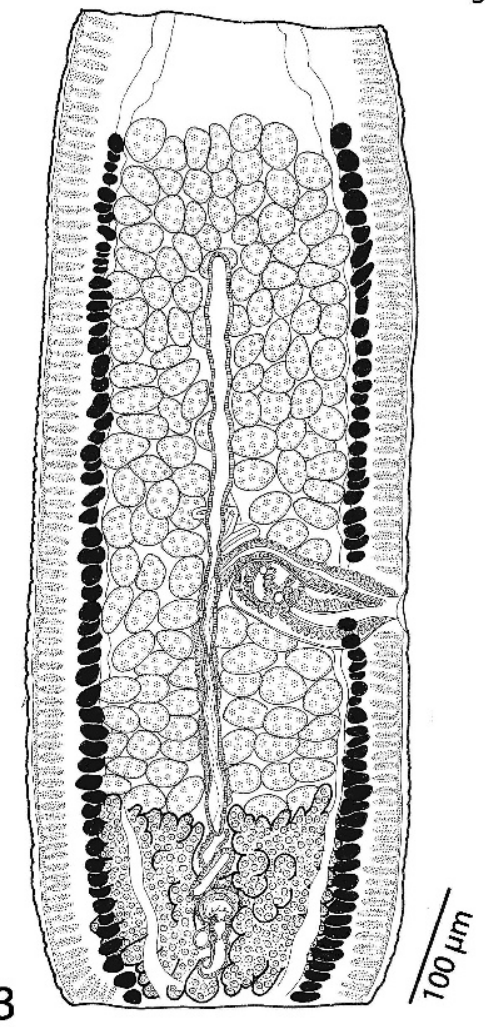

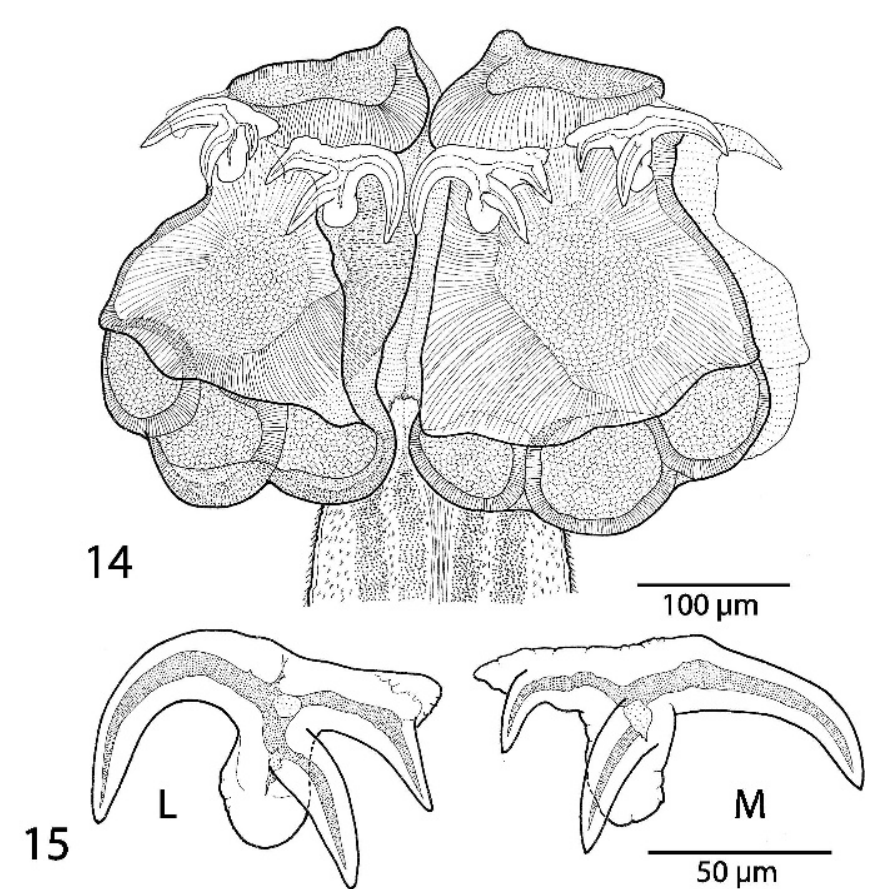

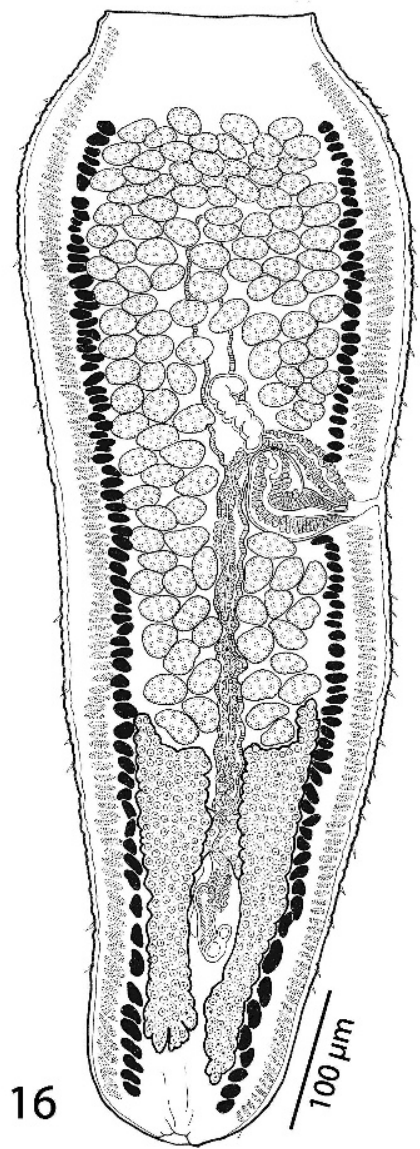

Figures 11-13. Triloculatum triloculatum (Linton, 1901) n. comb. (11) Scolex. (12) Hooks. (13) Terminal proglottid. Figures 14-16. Triloculatum andersonorum n. sp. (14) Scolex. (15) Hooks. (16) Terminal proglottid. Abbreviations: L, lateral hook; M, medial hook. 


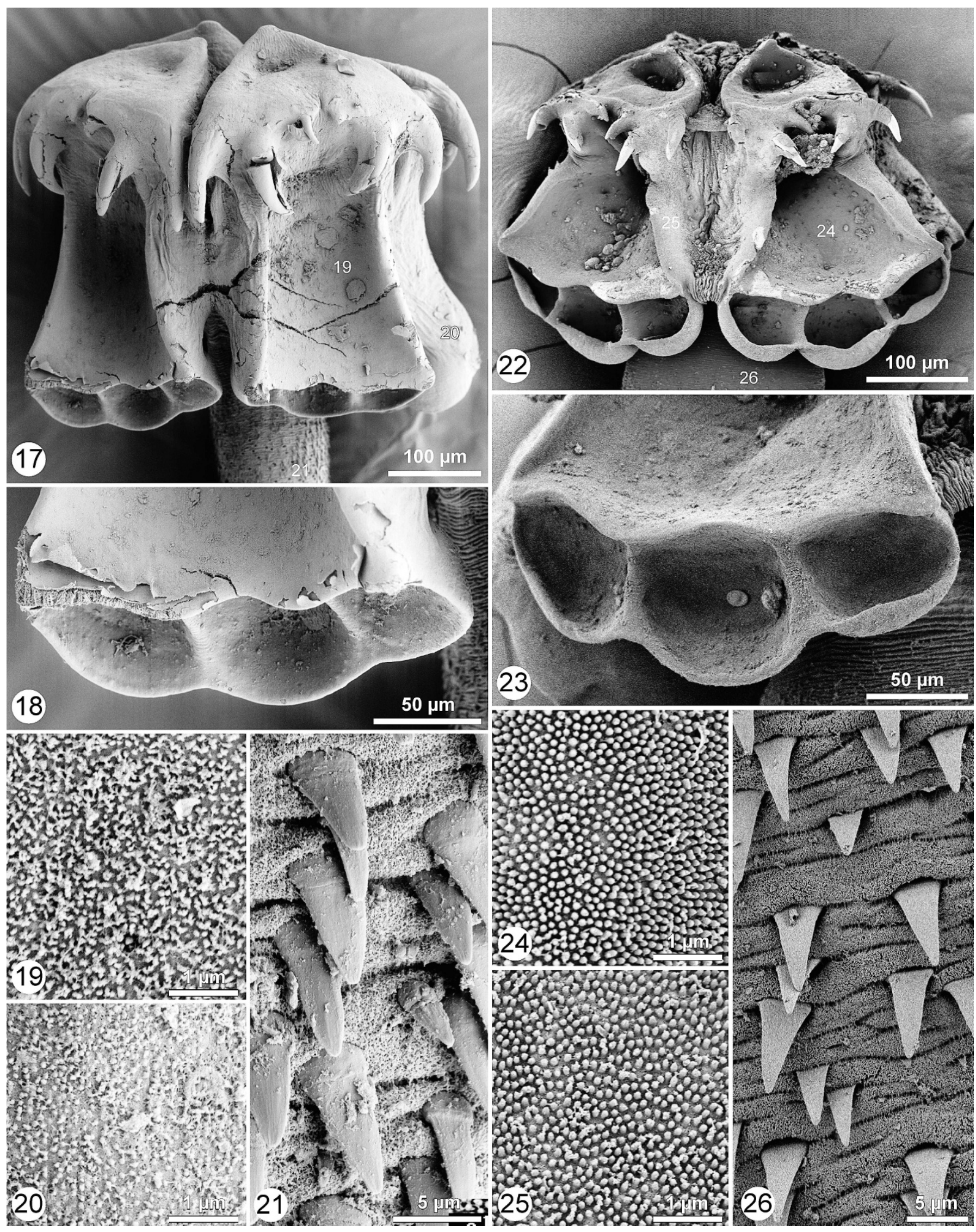


consisting of 2 columns of follicles, extending almost entire length of proglottid, interrupted by vagina and cirrus sac, uninterrupted by ovary; vitelline follicles $7-15$ long by $8-19$ wide. Uterus ventral, extending anteriorly from level of ovarian bridge, stopping 4 testes-lengths short of anterior margin of field of testes. Excretory ducts 4, lateral. Eggs not observed.

\section{Taxonomic summary}

Type host: Negaprion acutidens (Rüppell, 1837), sicklefin lemon shark (Elasmobranchii; Carcharhinidae).

Additional hosts: None.

Type locality: Gulf of Carpentaria near Weipa $\left(12^{\circ} 39^{\prime} 60.00^{\prime \prime} \mathrm{S}\right.$, $\left.141^{\circ} 52^{\prime} 0.00^{\prime \prime} \mathrm{E}\right)$, Queensland, Australia.

Additional localities: None.

Site of infection: Spiral intestine.

Specimens deposited: QM No. G231300 (holotype) and QM Nos. G231301-G231302 (2 paratypes); USNPC No. 101667 (1 paratype); LRP Nos. 4300-4302 (3 paratypes including SEM strobilar vouchers); scolices prepared for SEM retained in the senior author's personal collection.

Etymology: This species is named in honor of the Anderson family of Ashford, Connecticut in recognition of their enthusiastic appreciation of all things parasitological, despite their otherwise non-parasitological interests.

\section{Remarks}

Overall, this is the smallest of known Triloculatum species (see Figs. 510). Triloculatum andersonorum $\mathrm{n}$. sp. is readily distinguished from $T$. triloculatum in that it possesses a greater number of proglottids (78-99 vs. $54+$ ), a shorter scolex proper (340-448 vs. 534-667) and cirrus sac (83-109 vs. 134-227), lateral hooks with abaxial prongs that are much-less recurved than those in the latter species, and craspedote rather than acraspedote proglottids. To date, this is the only species of Triloculatum known from a carcharhinid shark outside of the genus Carcharhinus Blainville, 1816

\section{Triloculatum bullardi $\mathrm{n}$. sp.}

(Figs. 7, 27-29, 33-37, 59-60)

Description (based on 20 specimens: 17 whole mounts of mature worms, cross sections of 1 proglottid, and 2 scolices prepared for SEM): Worms $11.7-25.1 \mathrm{~mm}$ long, euapolytic, greatest width at proglottid 8-20 from posterior end, 791-1,175 wide; proglottids 60-93 per worm, acraspedote. Scolex consisting of scolex proper and cephalic peduncle. Scolex proper 615-797 long by 624-722 wide, with 4 bothridia. Bothridia 552-741 long by $288-348$ wide, each with anterior muscular pad in form of sucker, and 2 subequal loculi divided by horizontal septum. Anterior loculus 359-546 long, bearing 1 pair of hooks with 3 unequal prongs and talon; posterior loculus shorter than anterior loculus, divided into 3 subloculi (Fig. 34); subloculi approximately equal in width, $78-123$ wide. Hooks tri-pronged, smooth, hollow; lateral hook lengths: A $80-129$, B 95-123, C 102-119, D 97-142, E 20-29, F 39-52; medial hook lengths: A' 88-132, B' 107-136, C' 109-127, $\mathrm{D}^{\prime} 128-159, \mathrm{E}^{\prime} 38-54, \mathrm{~F}^{\prime}$ 37-65; internal hook channel continuous between prongs, extending into talon; lateral and medial hooks approximately equal in length. Cephalic peduncle with inconspicuous posterior limit.

Distal and proximal bothridial surfaces, apex of scolex, and scolex proper between bothridia covered with short filitriches only (Figs. 35-36). Cephalic peduncle covered with large, blade-like spinitriches and long filitriches (Fig. 37).

Immature proglottids 58-88 in number, most wider than long, posteriormost immature proglottid 535-961 long by $695-1,068$ wide; mature proglottids $2-7$ in number, terminal proglottid $1,257-2,447$ long by
528-855 wide; gravid proglottids not observed. Testes oval, 150-211 in number, of these 18-36 postvaginal, $27-70$ long by $40-87$ wide, in approx. 8-9 columns anterior to cirrus sac, 1 layer deep in cross section (Fig. 59). Vas deferens minimal, coiling anteriorly and laterally to cirrus sac, entering cirrus sac at its distal end. Cirrus sac oval, 205-318 long by 89152 wide, not reaching midline of proglottid, containing coiled cirrus; cirrus covered with spinitriches. Genital pores marginal, irregularly alternating, 45-60\% of proglottid length from posterior end in terminal proglottids. Vagina sinuous, extending along midline of proglottid from ootype region to anterior margin of cirrus sac, then laterally along anterior margin of cirrus sac, opening into common genital atrium anterior to cirrus sac; vaginal sphincter not observed; seminal receptacle present. Ovary near posterior margin of proglottid, $\mathrm{H}$-shaped in frontal view, 372 834 long by $325-533$ wide, bi-lobed in cross section (Fig. 60), lobulated; ovarian isthmus slightly anterior to middle of ovary. Mehlis' gland posterior to ovarian isthmus. Vitellarium follicular, in 2 lateral bands; each band consisting of multiple columns of follicles, extending almost entire length of proglottid, interrupted by cirrus sac, uninterrupted by vagina and ovary; vitelline follicles $15-40$ long by $22-55$ wide. Uterus ventral, extending anteriorly from level of ovarian bridge, stopping 4 testes-lengths short of anterior margin of field of testes. Excretory ducts 4, lateral. Eggs not observed.

\section{Taxonomic summary}

Type host: Carcharhinus brevipinna (Rüppell, 1837), spinner shark (Elasmobranchii; Carcharhinidae).

Additional hosts: None.

Type locality: Near oil rig MO-990 $\left(29^{\circ} 58^{\prime} 58.20^{\prime \prime} \mathrm{N}, 88^{\circ} 36^{\prime} 16.80^{\prime \prime} \mathrm{W}\right)$, Louisiana, Gulf of Mexico.

Additional localities: Southwest end of Horn Island $\left(30^{\circ} 13^{\prime} 20.72^{\prime \prime} \mathrm{N}\right.$, $\left.88^{\circ} 47^{\prime} 13.64^{\prime \prime} \mathrm{W}\right)$, Mississippi, Gulf of Mexico.

Site of infection: Spiral intestine.

Specimens deposited: USNPC No. 101668 (holotype) and USNPC No. 101669 (9 paratypes including cross sections of 1 proglottid and whole mount of its strobilar voucher); LRP Nos. 4307-4316 (10 paratypes including SEM strobilar vouchers); scolices prepared for SEM retained in junior author's personal collection.

Etymology: This species is named in honor Dr. Stephen A. Bullard, without whose expert assistance the collection of the challenging sharks that hosted the type material of this species would not have been possible.

\section{Remarks}

This is the largest of known Triloculatum species (see Figs. 5-10). It differs conspicuously from $T$. triloculatum in that it possesses more proglottids (60-93 vs. 54+) and from $T$. andersonorum in that it is much longer (11.7-25.1 vs. $7.85-11.7 \mathrm{~mm})$. It further differs from $T$. andersonorum in its possession of a longer scolex proper (615-797 vs. 340-448), a greater number of testes (150-211 vs. 82-122), and acraspedote rather than craspedote proglottids. It differs further from $T$. triloculatum in its possession of lateral bands of vitelline follicles that are each comprised of multiple, rather than 2 , columns of vitelline follicles.

\section{Triloculatum geeceearelensis $\mathbf{n}$. sp.}

(Figs. 8, 30-32, 38-42, 64-65)

Description (based on 14 specimens: 11 whole mounts of mature worms, cross sections of 1 proglottid, and 2 scolices prepared for SEM): Worms 10.5-17.7 mm long, euapolytic, greatest width at proglottid 3-15 from posterior end, 665-955 wide; proglottids 41-69 per worm, acraspedote. Scolex consisting of scolex proper and cephalic peduncle. Scolex proper 505-669 long by 511-698 wide, with 4 bothridia. Bothridia 478-662 long by $250-329$ wide, each with anterior muscular pad in form of sucker, and 2

$\leftarrow$

FIGURES 17-21. Scanning electron micrographs of Triloculatum triloculatum (Linton, 1901) n. comb. (17) Scolex. Small numbers indicate locations of details shown in Figs. 19-21. (18) Posterior loculus divided into 3 subloculi. (19) Filitriches on distal bothridial surface. (20) Filitriches on proximal bothridial surface. (21) Spinitriches and filitriches on cephalic peduncle. Figures 22-26. Scanning electron micrographs of Triloculatum andersonorum $\mathrm{n}$. sp. (22) Scolex. Small numbers indicate locations of details shown in Figures 24-26. (23) Posterior loculus divided into 3 subloculi. (24) Filitriches on distal bothridial surface. (25) Filitriches on proximal bothridial surface. (26) Spinitriches and filitriches on cephalic peduncle. 
subequal loculi divided by horizontal septum. Anterior loculus 309-534 long, bearing 1 pair of hooks with 3 unequal prongs and talon; posterior loculus shorter than anterior loculus, divided into 3 subloculi (Fig. 36); subloculi approximately equal in width, 76-114 wide. Hooks tri-pronged, smooth, hollow; lateral hook lengths: A 87-134, B 86-113, C 93-122, D 121-156, E 16-25, F 34-51; medial hook lengths: A' 88-139, B' 100-144, $\mathrm{C}^{\prime}$ 95-107, $\mathrm{D}^{\prime}$ 121-161, $\mathrm{E}^{\prime} 36-48, \mathrm{~F}^{\prime}$ 36-45; internal hook channel continuous between prongs, extending into talon; lateral and medial hooks approximately equal in length. Cephalic peduncle with inconspicuous posterior limit.

Distal and proximal bothridial surfaces, apex of scolex, and scolex proper between bothridia covered with short filitriches only (Figs. 40-41). Cephalic peduncle covered with large, blade-like spinitriches and long filitriches (Fig. 42).

Immature proglottids 39-67 in number, most wider than long, posteriormost immature proglottid 433-785 long by 639-891 wide; mature proglottids $2-4$ in number, terminal proglottid 1,065-2,140 long by $493-847$ wide; gravid proglottids not observed. Testes oval, 117-178 in number, of these 12-29 postvaginal, 36-61 long by 44-73 wide, in approx. 7-11 columns anterior to cirrus sac, 1 layer deep in cross section (Fig. 64). Vas deferens minimal, coiling to cirrus sac, entering cirrus sac at its distal end. Cirrus sac oval, 180-260 long by 93-173 wide, not reaching midline of proglottid, containing coiled cirrus; cirrus covered with spinitriches. Genital pores marginal, irregularly alternating, 49-56\% of proglottid length from posterior end in terminal proglottids. Vagina weakly sinuous, extending along midline of proglottid from ootype region to anterior margin of cirrus sac, then laterally along anterior margin of cirrus sac, opening into common genital atrium anterior to cirrus sac; vaginal sphincter not observed; seminal receptacle present. Ovary near posterior margin of proglottid, H-shaped in frontal view, 305-610 long by 310-606 wide, bi-lobed in cross section (Fig. 65), lobulated; ovarian isthmus slightly anterior to middle of ovary. Mehlis' gland posterior to ovarian isthmus. Vitellarium follicular, in 2 lateral bands; each band consisting of multiple columns of follicles, extending almost entire length of proglottid, interrupted by vagina and cirrus sac, uninterrupted by ovary; vitelline follicles $17-39$ long by $28-71$ wide. Uterus ventral, extending anteriorly from level of ovarian bridge, stopping 4 testeslengths short of anterior margin of field of testes. Excretory ducts 4, lateral. Eggs not observed.

\section{Taxonomic summary}

Type host: Carcharhinus isodon (Valenciennes, 1839), finetooth shark (Elasmobranchii; Carcharhinidae).

Additional hosts: None.

Type locality: Off Round Island $\left(30^{\circ} 17^{\prime} 42.45^{\prime \prime} \mathrm{N}, 88^{\circ} 35^{\prime} 11.55^{\prime \prime} \mathrm{W}\right)$, Mississippi, Gulf of Mexico.

Additional localities: Off Indian Pass $\left(29^{\circ} 40^{\prime} 8.05^{\prime \prime} \mathrm{N}, 85^{\circ} 13^{\prime} 30.17^{\prime \prime} \mathrm{W}\right)$

Florida, Gulf of Mexico.

Site of infection: Spiral intestine.

Specimens deposited: USNPC No. 101659 (holotype) and USNPC Nos. 101660-101661 (6 paratypes including cross sections of 1 proglottid and whole mount of its strobilar voucher); LRP Nos. 4285-4291 (7 paratypes including SEM strobilar vouchers); scolices prepared for SEM retained in junior author's personal collection.

Etymology: This species is named for the Gulf Coast Research Laboratory, i.e., "GCRL," University of Southern Mississippi, the excellent facilities of which were made freely available to the authors.

\section{Remarks}

Triloculatum geeceearelensis n. sp. differs from $T$. triloculatum and $T$. andersonorum in its possession of lateral bands of vitelline follicles that are each comprised of multiple, rather than 2, columns of vitelline follicles. It differs further from $T$. triloculatum in possessing a wider posteriormost immature proglottid (639-891 vs. 308-615) and from T. andersonorum in possessing fewer proglottids (41-69 vs. 78-99) and in that it possesses acraspedote rather than craspedote proglottids. This species most closely resembles $T$. bullardi, but differs in the medial extent of the ovarian follicles, which reach the midline of the proglottid in the latter species, but not in the former species. In addition, the anterior margin of the muscular pad is more erect in $T$. bullardi than it is in $T$. geeceearelensis.

\section{Triloculatum jodyi n. sp.}

(Figs. 9, 43-45, 49-53)

Description (based on 5 specimens: 3 whole mounts of mature worms and 2 scolices prepared for SEM): Worms $7.6-11.1 \mathrm{~mm}$ long, euapolytic, greatest width at proglottid 33-47 from posterior end, 466-519 wide; proglottids 44-50 per worm, acraspedote. Scolex consisting of scolex proper and cephalic peduncle. Scolex proper $476-577$ long by $480-518$ wide, with 4 bothridia. Bothridia 454-577 long by 209-267 wide, each with anterior muscular pad in form of sucker, and 2 subequal loculi divided by horizontal septum. Anterior loculus 326-393 long, bearing 1 pair of hooks with 3 unequal prongs and talon; posterior loculus shorter than anterior loculus, divided into 3 subloculi (Fig. 50); subloculi approximately equal in width, 76-106 wide. Hooks tri-pronged, smooth, hollow; lateral hook lengths: A 78-112, B 87-105, C 104-106, D 111-133, E 23-26, F 37-52; medial hook lengths: A' 86-107, B' 100-117, C' 85-106, D' 128-139, E' 40-44, $\mathrm{F}^{\prime}$ 32-42; internal hook channel continuous between prongs, extending into talon; lateral and medial hooks approximately equal in length. Cephalic peduncle with inconspicuous posterior limit.

Distal and proximal bothridial surfaces, apex of scolex, and scolex proper between bothridia covered with short filitriches only (Figs. 51-52). Cephalic peduncle covered with large, blade-like spinitriches and long filitriches (Fig. 53).

Immature proglottids $42-49$ in number, initially wider than long, posteriormost immature proglottid $602-1,130$ long by 381-490 wide; mature proglottids 1 in number, 781-1,460 long by 352-507 wide; gravid proglottids not observed. Testes oval, 73-133 in number, of these 12-21 postvaginal, 22-42 long by 37-61 wide, in approx. 5-7 columns anterior to cirrus sac, 1 layer deep in cross section. Vas deferens minimal, coiling anteriorly to cirrus sac, entering cirrus sac at its distal end. Cirrus sac oval, $250-468$ long by $47-88$ wide, extending to midline of proglottid, containing coiled cirrus; cirrus covered with spinitriches. Genital pores marginal, irregularly alternating, 52-55\% of proglottid length from posterior end in terminal proglottids. Vagina weakly sinuous, extending along midline of proglottid from ootype region to anterior margin of cirrus sac, then laterally along anterior margin of cirrus sac, opening into common genital atrium anterior to cirrus sac; vaginal sphincter not observed; seminal receptacle not observed. Ovary near posterior margin of proglottid, H-shaped in frontal view, 250-468 long by 229-351 wide, bilobed in cross section, lobulated; ovarian isthmus slightly anterior to middle of ovary. Mehlis' gland posterior to ovarian isthmus. Vitellarium follicular, in 2 lateral bands; each band consisting of multiple columns of follicles, extending almost entire length of proglottid, essentially uninterrupted by vagina, cirrus sac, or ovary; vitelline follicles 13-21 long by 25 38 wide. Uterus ventral, extending anteriorly from level of ovarian bridge, stopping 3-4 testes-lengths short of anterior margin of field of testes. Excretory ducts 4, lateral. Eggs not observed.

\section{Taxonomic summary}

Type host: Carcharhinus acronotus (Poey, 1860), blacknose shark (Elasmobranchii; Carcharhinidae)

Additional hosts: None.

Type locality: Near oil rig MO-990 $\left(29^{\circ} 58^{\prime} 58.20^{\prime \prime} \mathrm{N}, 88^{\circ} 36^{\prime} 16.80^{\prime \prime} \mathrm{W}\right)$, Louisiana, Gulf of Mexico.

Additional localities: None.

Site of infection: Spiral intestine.

Specimens deposited: USNPC No. 101662 (holotype) and USNPC No. 101663 (1 paratype); LRP Nos. $4292-4294$ (3 paratypes including SEM strobilar vouchers); scolices prepared for SEM retained in junior author's personal collection.

Etymology: This species is named in honor of Mr. Jody Peterson for his assistance with the collection of sharks from the northern Gulf of Mexico, including the type host of this species.

\section{Remarks}

Triloculatum jodyi $\mathrm{n}$. sp. is shorter than T. triloculatum (7.6-11.1 vs. $18.8 \mathrm{~mm})$, possesses a narrower scolex (480-518 vs. 606-738), a pore positioned more anteriorly in the proglottid (52-55 vs. $41-50 \%$ from posterior end), and lateral bands of vitelline follicles that are each comprised of multiple, rather than 2 , columns of vitelline follicles. Triloculatum jodyi $\mathrm{n}$. sp. possesses fewer proglottids than $T$. andersonorum and $T$. bullardi (44-50 vs. $78-99$ and 60-93, respectively) and fewer mature proglottids than $T$. geeceearenlensis and $T$. bullardi (1 vs. $2-4$ and 2-7, 

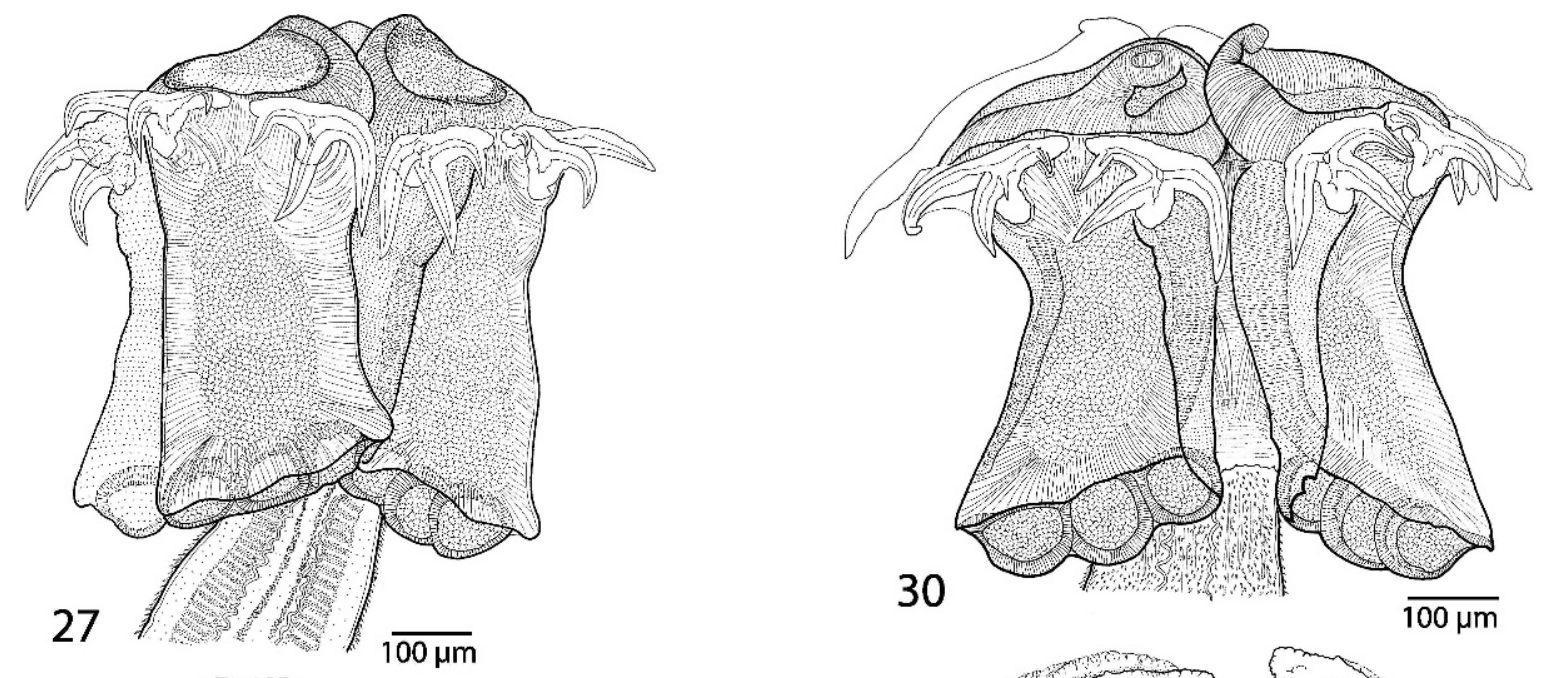
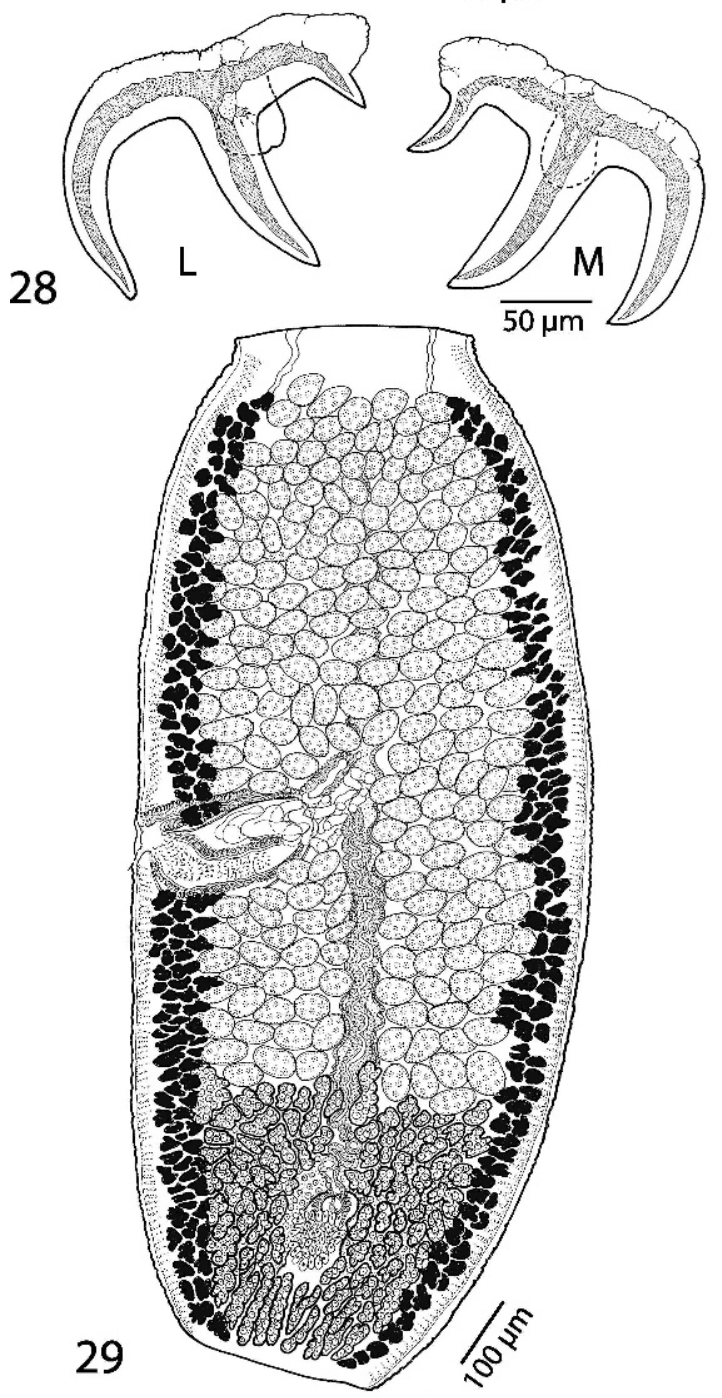
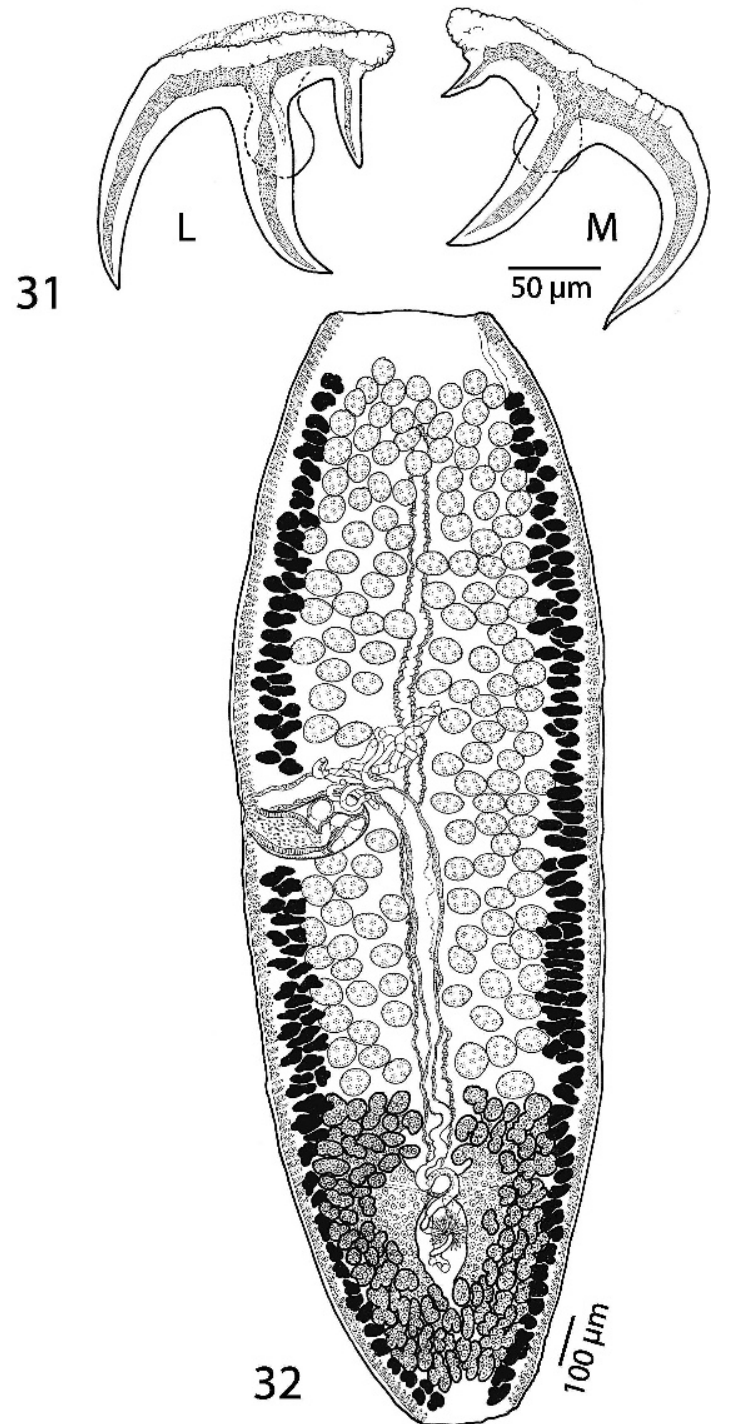

Figures 27-29. Triloculatum bullardi $\mathrm{n}$. sp. (27) Scolex. (28) Hooks. (29) Terminal proglottid. Figures 30-32. Triloculatum geeceearelensis n. sp. (30) Scolex. (31) Hooks. (32) Terminal proglottid. Abbreviations: L, lateral hook; M, medial hook.

respectively). It further differs from $T$. andersonorum in possessing acraspedote rather than craspedote proglottids and abaxial prongs of the lateral hooks that are much more recurved than those seen in the latter species, and from $T$. geeceearenlensis in its narrower maximum width
(466-519 vs. $719-1,175)$ and narrower cirrus sac (47-88 vs. 93-173). Although no material of " $P$. triloculatum" from $C$. acronotus in North Carolina was deposited by Campbell (1975), given the host, we suspect his material may have been conspecific with $T$. jodyi $\mathrm{n}$. sp. 


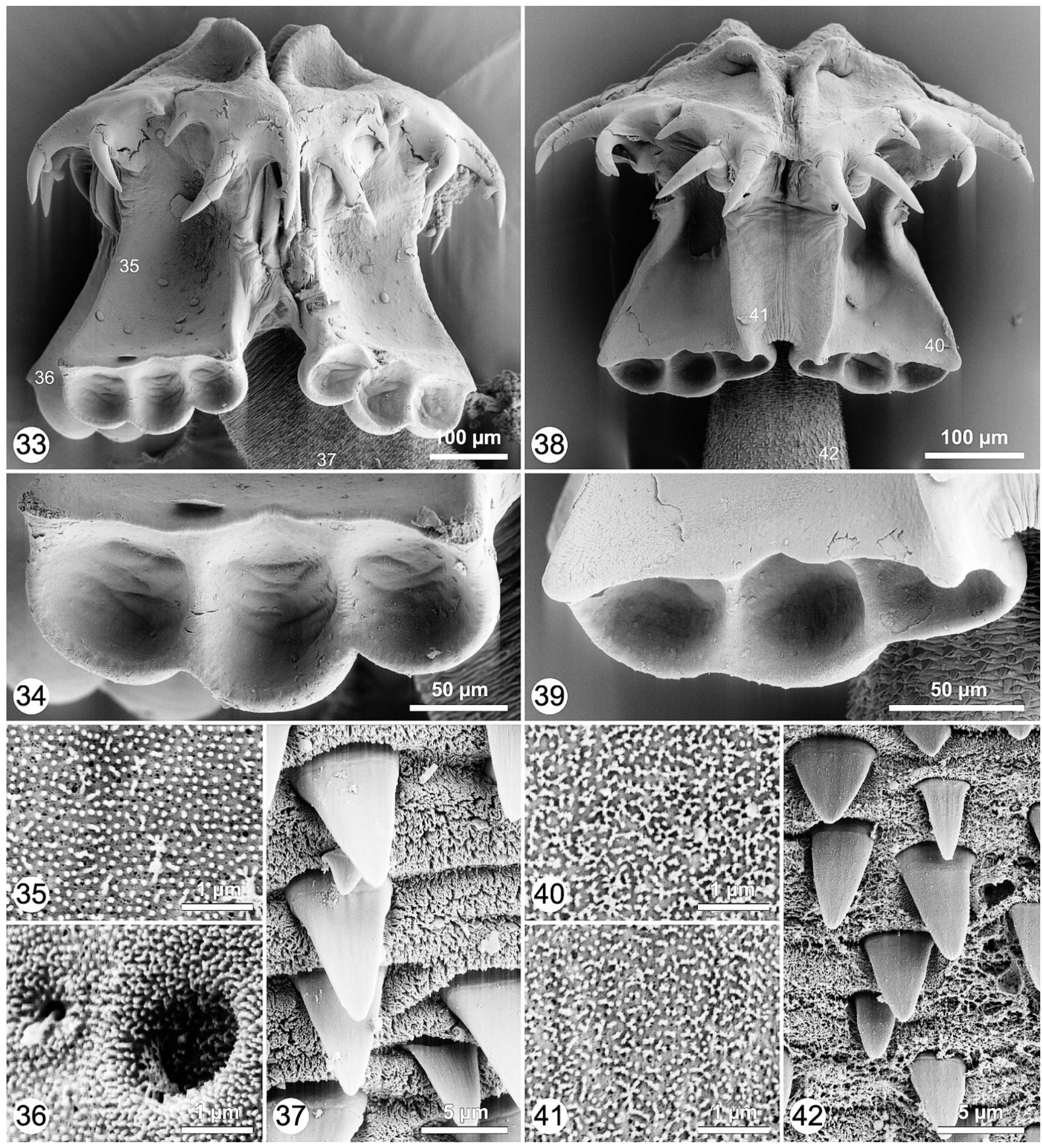

FIGURES 33-37. Scanning electron micrographs of Triloculatum bullardi n. sp. (33) Scolex. Small numbers indicate locations of details shown in Figures 35-37. (34) Posterior loculus divided into 3 subloculi. (35) Filitriches on distal bothridial surface. (36) Filitriches on proximal bothridial surface (37) Spinitriches and filitriches on cephalic peduncle. FiguREs 38-42. Scanning electron micrographs of Triloculatum geeceearelensis $\mathrm{n}$. sp. (38) Scolex. Small numbers indicate locations of details shown in Figures 40-42. (39) Posterior loculus divided into 3 subloculi. (40) Filitriches on distal bothridial surface. (41) Filitriches on proximal bothridial surface. (42) Spinitriches and filitriches on cephalic peduncle. 

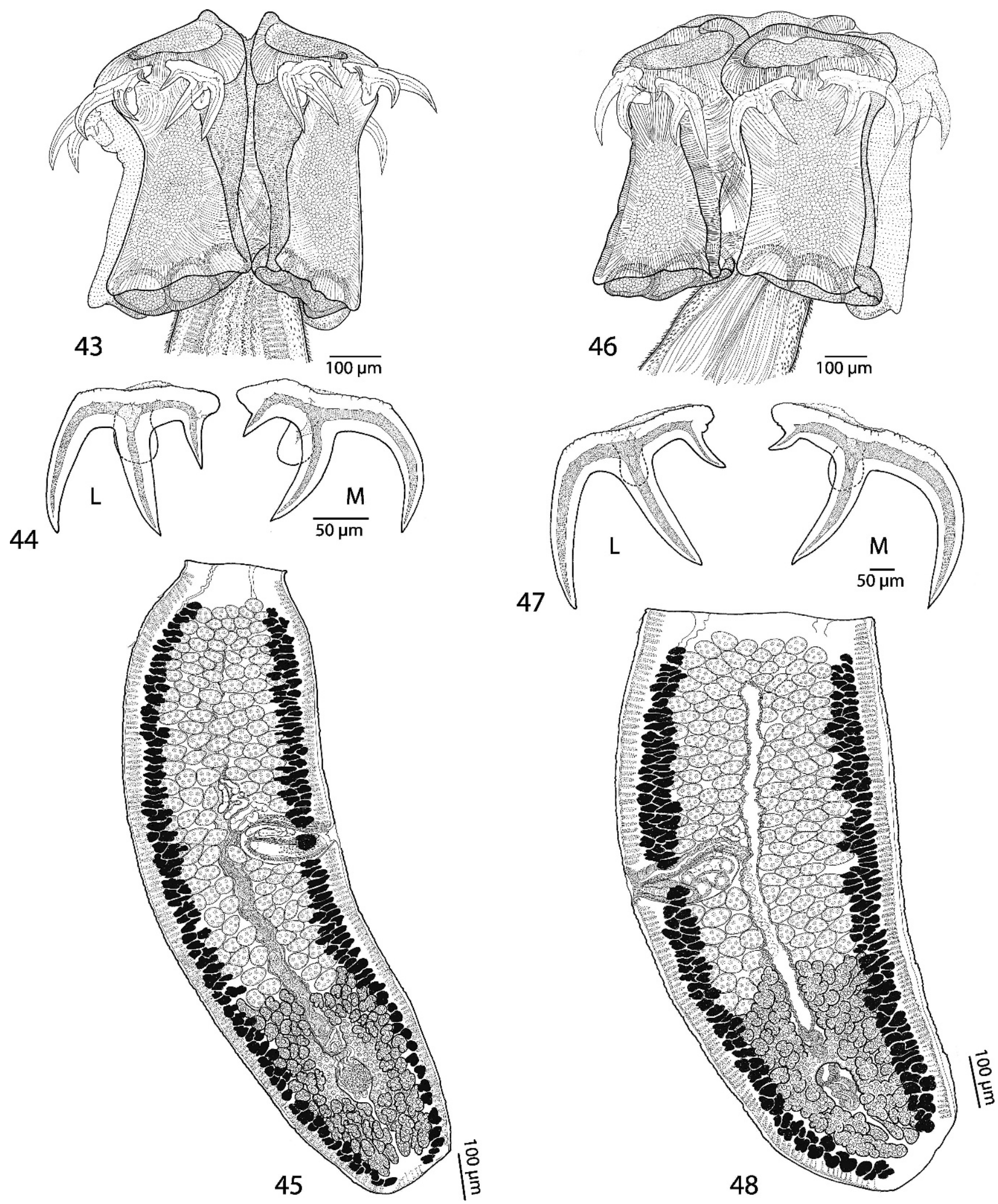

Figures 43-45. Triloculatum jodyi n. sp. (43) Scolex. (44) Hooks. (45) Terminal proglottid. Figures 46-48. Triloculatum oregontwoae n. sp. (46) Scolex. (47) Hooks. (48) Terminal proglottid. Abbreviations: L, lateral hook; M, medial hook. 


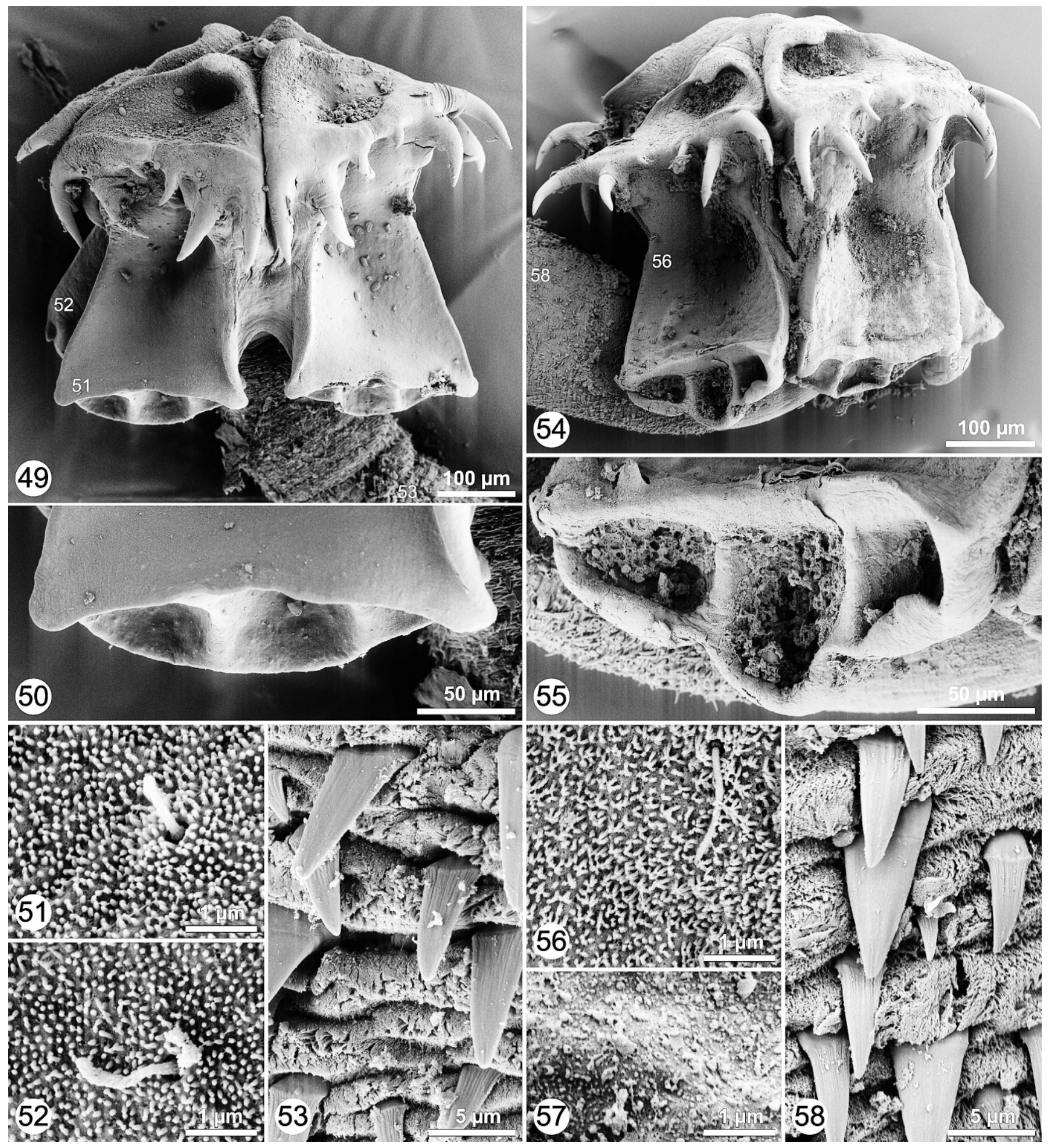

FIgURES 49-53. Scanning electron micrographs of Triloculatum jodyi n. sp. (49) Scolex. Small numbers indicate locations of details shown in Figures 51-53. (50) Posterior loculus divided into 3 subloculi. (51) Filitriches on distal bothridial surface. (52) Filitriches on proximal bothridial surface (53) Spinitriches and filitriches on cephalic peduncle. Figures 54-58. Scanning electron micrographs of Triloculatum oregontwoae n. sp. (54) Scolex. Small numbers indicate locations of details shown in Figures 56-58. (55) Posterior loculus divided into 3 subloculi. (56) Filitriches on distal bothridial surface. (57) Filitriches on proximal bothridial surface. (58) Spinitriches and filitriches on cephalic peduncle. 


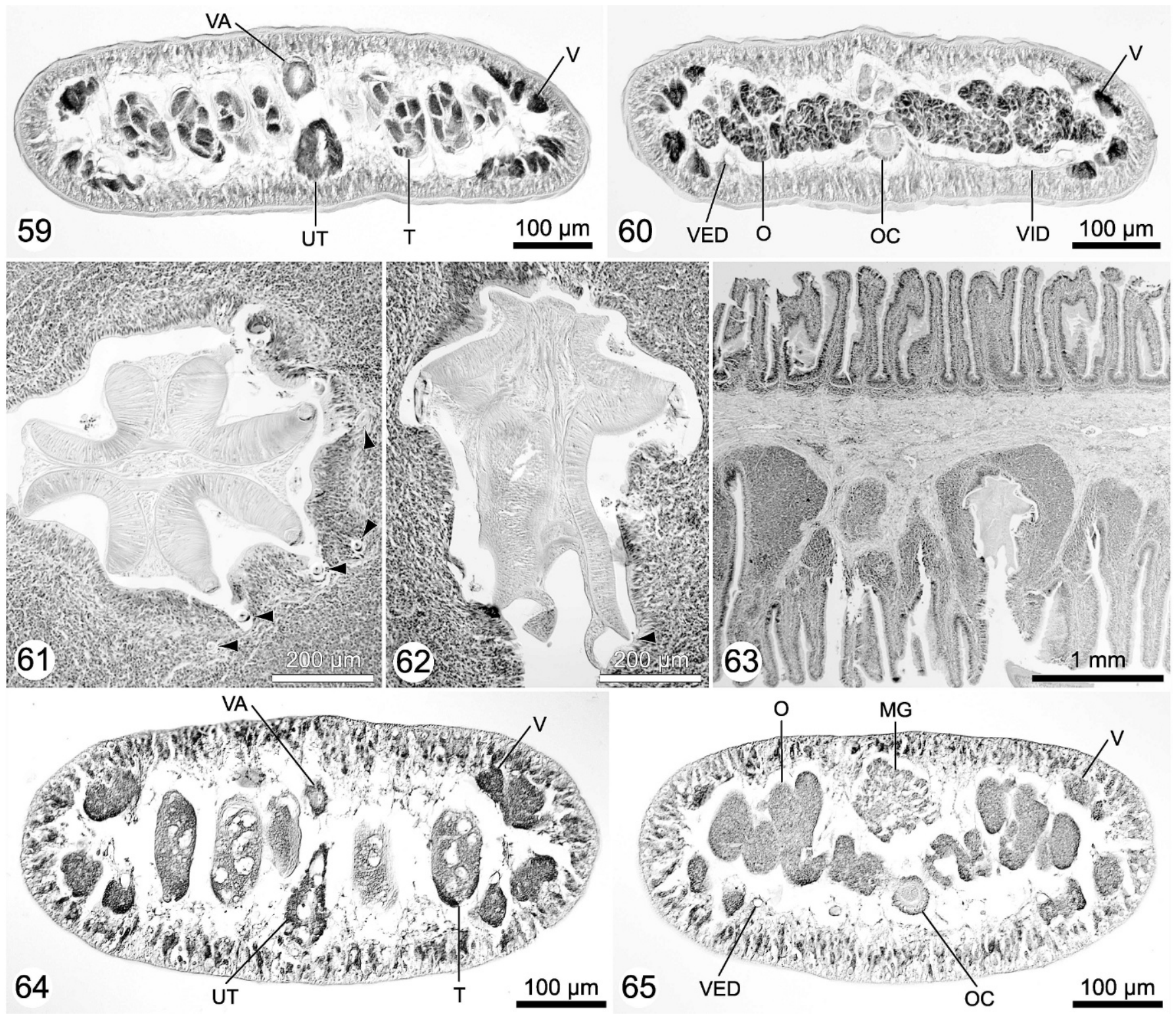

FIGURES 59-60. Cross sections through mature proglottid of Triloculatum bullardi $\mathrm{n}$. sp. (59) Cross section at level midway between ovary and cirrus sac. (60) Cross section at level of ovarian bridge. FIgUREs 61-63. Sections through mucosa of scroll type spiral intestine of Carcharhinus brevipinna with scolex of Triloculatum bullardi $\mathrm{n}$. sp. in situ. (61) Cross section through scolex, at level of hooks, parallel to mucosal surface. Arrowheads indicate hooks embedded in mucosal surface. (62) Longitudinal section through scolex perpendicular to mucosal surface. Arrowhead indicates free anterior margin of posterior loculus. (63) Lower magnification view of scolex in situ showing large mucosal ridges and crypts of posterior inner region (bottom of Fig. 63) of scroll and smaller ridges and crypts of posterior outer surface (top of Fig. 63) of mucosal scroll. Figures 64-65. Cross sections through mature proglottid of Triloculatum geeceearelensis $\mathrm{n}$. sp. (64) Cross section at level midway between ovary and cirrus sac. (65) Cross section at level of ovarian bridge. Abbreviations: MG, Mehlis' gland; O, ovary; OC, ovicapt; T, testis; UT, uterus; V, vitelline follicle; VA, vagina; VED, ventral excretory duct; VID, vitelline duct.

Triloculatum oregontwoae $\mathrm{n} . \mathrm{sp}$.

(Figs. 10, 46-48, 54-58)

Description (based on 10 specimens: 3 whole mounts of mature worms and 6 whole mounts of immature or incomplete worms, and 1 scolex prepared for SEM): Worms $9.2-19.8 \mathrm{~mm}$ long, euapolytic, greatest width at proglottid 33-84 from posterior end, 440-779 wide; proglottids 54-94 per worm, acraspedote. Scolex consisting of scolex proper and cephalic peduncle. Scolex proper 609-927 long by 624-840 wide, with 4 bothridia. Bothridia 583-846 long by 300-400 wide, each with anterior muscular pad in form of sucker, and 2 subequal loculi divided by horizontal septum. Anterior loculus 443-568 long, bearing 1 pair of hooks with 3 unequal prongs and talon; posterior loculus shorter than anterior loculus, divided into 3 subloculi (Fig. 55); subloculi approximately equal in width, 98-143 wide. Hooks tri-pronged, smooth, hollow; lateral hook lengths: A 140 151, B 123-140, C 115-131, D 129-163, E 21-27, F 39-56; medial hook lengths: A' 123-150, B' 127-151, C' 107-132, D' 129-174, E' 43-54, F' 39-55; internal hook channel continuous between prongs, extending into talon; lateral and medial hooks approximately equal in length. Cephalic peduncle with inconspicuous posterior limit.

Distal and proximal bothridial surfaces, apex of scolex, and scolex proper between bothridia covered with short filitriches only (Figs. 56-57). Cephalic peduncle covered with large, blade-like spinitriches and long filitriches (Fig. 58). 
Immature proglottids 54-92 in number, initially wider than long, posteriormost immature proglottid 593-637 long by 532-619 wide; mature proglottids $0-2$ in number, 844-969 long by $517-613$ wide; gravid proglottids not observed. Testes oval, 139-190 in number, of these 17-32 postvaginal, 22-37 long by 42-49 wide, in approx. 7-11 columns anterior to cirrus sac, 1 layer deep in cross section. Vas deferens minimal, coiling anteriorly to cirrus sac, entering cirrus sac at its distal end. Cirrus sac oval, 173-200 long by 42-70 wide, approaching midline of proglottid, containing coiled cirrus; cirrus covered with spinitriches. Genital pores marginal, irregularly alternating, $43-55 \%$ of proglottid length from posterior end in terminal proglottids. Vagina sinuous, extending along midline of proglottid from ootype region to anterior margin of cirrus sac, then laterally along anterior margin of cirrus sac, opening into common genital atrium anterior to cirrus sac; vaginal sphincter not observed; seminal receptacle not observed. Ovary near posterior margin of proglottid, $\mathrm{H}$-shaped in frontal view, 169-310 long by $288-380$ wide, bi-lobed in cross section, lobulated; ovarian isthmus slightly anterior to middle of ovary. Mehlis' gland posterior to ovarian isthmus. Vitellarium follicular, in 2 lateral bands; each band consisting of multiple columns of follicles, extending almost entire length of proglottid, slightly interrupted by vagina and cirrus sac, uninterrupted by ovary; vitelline follicles $11-21$ long by $25-50$ wide. Uterus ventral, extending anteriorly from level of ovarian bridge, stopping 3 testes-lengths short of anterior margin of field of testes. Excretory ducts 4, lateral. Eggs not observed.

\section{Taxonomic summary}

Type host: Carcharhinus plumbeus (Nardo, 1827), sandbar shark (Elasmobranchii; Carcharhinidae).

Additional hosts: None.

Type locality: Off Florida, slightly west of Fort Walton Beach $\left(30^{\circ} 21^{\prime} 07.80^{\prime \prime} \mathrm{N}, 86^{\circ} 43^{\prime} 53.40^{\prime \prime} \mathrm{W}\right)$, Gulf of Mexico.

Additional localities: Off the Alabama-Florida state line $\left(30^{\circ} 07^{\prime} 60.00^{\prime \prime} \mathrm{N}, 87^{\circ} 27^{\prime} 0.00^{\prime \prime} \mathrm{W}\right)$, Gulf of Mexico.

Site of infection: Spiral intestine.

Specimens deposited: USNPC No. 101664 (holotype) and USNPC Nos. 101665-101666 (4 paratypes); LRP Nos. 4295-4299 (5 paratypes including SEM strobilar voucher); scolex prepared for SEM retained in junior author's personal collection.

Additional material examined: USNPC Nos. 7686 and 35804 (vouchers) ex C. plumbeus (as C. milberti), Woods Hole, Massachusetts.

Etymology: This species is named for the National Marine Fisheries Service Research Vessel, the Oregon II, for her facilitation of the collection of the type material of this species.

\section{Remarks}

With respect to its 5 described congeners, $T$. oregontwoae $\mathrm{n}$. $\mathrm{sp}$. possesses the longest abaxial prong of the lateral hook (140-151 vs. 101128 in T. triloculatum, 107-117 in T. andersonorum, 80-129 in T. bullardi, 87-134 in T. geeceearenlensis, and 78-112 in T. jodyi). In addition, $T$. oregontwoae $\mathrm{n}$. sp. differs from $T$. andersonorum and $T$. jodyi in its possession of a larger scolex proper (609-927 long by 624-840 wide vs. $340-448$ long by $454-519$ wide and $476-577$ long by $480-518$ wide, respectively) and in its greater number of testes (139-190 vs. 82-122 and $73-133$, respectively). It differs further from $T$. bullardi in possessing narrower posteriormost immature proglottids $(532-619$ vs. $695-1,068)$ and a shorter ovary (169-310 vs. 372-834) and from T. geeceearelensis in possessing shorter posteriormost mature proglottids (844-969 vs. 1,065$2,140)$ and a narrower cirrus sac $(42-70$ vs. 93-173). It differs from $T$. triloculatum, and further differs from $T$. andersonorum, in its possession of lateral bands of vitelline follicles that are each comprised of multiple, rather than 2, columns of vitelline follicles. The specimens, identified as $P$. triloculatum (see Linton, 1924 and Caira, 1985) and collected from $C$. plumbeus by E. Linton (USNPC No. 7686) and G. MacCallum (USNPC No. 35804), are in poor condition and immature, respectively, and thus cannot be definitely identified as $T$. oregontwoae.

\section{Key to species of Triloculatum}

1a. 2 bands of vitelline follicles on each side of proglottid ...... 2 1b. $>2$ bands of vitelline follicles on each side of proglottid .... 3 2a. $<50$ proglottids; total length $<10 \mathrm{~mm}$; acraspedote T. triloculatum (ex C. obscurus)

2b. $\geq 50$ proglottids; total length $\geq 10 \mathrm{~mm}$; craspedote T. andersonorum (ex N. acutidens)

3a. $<135$ testes; $\leq 1$ mature proglottid . . T. jodyi (ex C. acronotus)

3b. Number of testes and number of mature proglottids not as above . . . 4

4a. Abaxial prong of lateral hook $\geq 140 \mu \mathrm{m}$ in length; mature proglottid length $\leq 1,000 \mu \mathrm{m} \quad \ldots \ldots \ldots \ldots$ T. oregontwoae (ex $C$. plumbeus)

4b. Abaxial prong of lateral hook $<140 \mu \mathrm{m}$ in length; mature proglottid length $>1,000 \mu \mathrm{m} \ldots \ldots \ldots \ldots$

5a. With 60-93 proglottids; anterior margin of muscular pad erect; up to 3 columns of vitelline follicles in each lateral band . . . . . . . T. bullardi (ex C. brevipinna)

5b. With 41-69 proglottids; anterior margin of apical region relaxed; up to 2 vitelline follicles in each lateral band

T. geeceearelensis (ex C. isodon)

\section{DISCUSSION}

At present, the host associations of Triloculatum appear to be much narrower than those of Phoreiobothrium. Whereas species in the latter genus collectively parasitize a diversity of carcharhinid and sphyrnid shark genera (see Caira et al., 2005), all 6 known species of Triloculatum are known only from a subset of carcharhinid taxa, with 5 species parasitizing species of Carcharhinus and 1 a species of Negaprion Whitley, 1940. No evidence of Triloculatum has been seen in any of the other carcharhinid genera known to host Phoreiobothrium species, that we have examined in some detail, to date. These include the monotypic genera Scoliodon Müller \& Henle, 1837 (21 specimens), Lamiopsis Gill, 1862 (5 specimens), Galeocerdo Müller \& Henle, 1837 (8 specimens), and Prionace Cantor, 1849 (100+ specimens), as well as 2-11 specimens of each of 5 species of Rhizoprionodon Whitley, 1929. Similarly, Triloculatum was not seen in the 3-10 specimens of the 5 species of hammerhead sharks (Sphyrna lewini [Griffith \& Smithe, 1834], Sphyrna mokarran [Rüppell, 1837], Sphyrna tiburo [Linnaeus, 1758], Sphyrna zygaena [Linnaeus, 1758], and Eusphyra blochii [Cuvier, 1817]) we have examined, in detail, to date.

It may be of note that the 6 shark species that are host to Triloculatum species are all relatively large, reaching maximum total lengths (TL) of at least $200 \mathrm{~cm}$ according to Compagno et al. (2005). This suggests that Triloculatum species may be restricted to larger shark species. Three elements of the survey work we have conducted on additional Carcharhinus and Negaprion species over the last decade support this hypothesis: (1) Although insufficient material is available for a formal description, the species reported as Phoreiobothrium n. sp. 3 by Caira et al. (2001) from the bull shark, C. leucas, possesses 3 subloculi and belongs in Triloculatum; the bull shark reaches a maximum TL $340 \mathrm{~cm}$; (2) although we have insufficient material to provide a description, we have some material of an additional new species with 3 subloculi from the second species of Negaprion, the Atlantic lemon shark, Negaprion brevirostris (Poey, 1868); this shark also reaches a maximum TL of $340 \mathrm{~cm}$; and (3) the following smaller species of Carcharhinus have not been found to host Triloculatum species, i.e., Carcharhinus amblyrhynchoides (Whiltley, 1934) (5 specimens), Carcharhinus cautus (Whitley, 1945) (10 specimens), Carcharhinus dussumieri (Valenciennes, 1839) (10 specimens), Carcharhinus fitzroyensis (Whitley, 1934) (3 specimens), Carcharhinus macloti (Müller \& Henle, 1939) (2 specimens), Carcharhinus melanopterus (Quoy \& Gaimard, 1824) (10 specimens), Carcharhinus sealei (Pietschmann, 1916) (5 specimens), and 
Carcharhinus sorrah (Valenciennes, 1839) (4 specimens). If our hypothesis is correct, given their maximum size according to Compagno et al. (2005), additional species of Carcharhinus that are likely to yield additional material of Triloculatum include Carcharhinus albimarginatus (Rüppell, 1837) (max TL $300 \mathrm{~cm}$ ), Carcharhinus altimus (Springer, 1950) (max TL $300 \mathrm{~cm}$ ), Carcharhinus amblyrhynchos (Bleeker, 1856) (max TL $255 \mathrm{~cm}$ ), Carcharhinus amboinensis (Müller \& Henle, 1839) (max TL $280 \mathrm{~cm}$ ), Carcharhinus brachyurus (Günther, 1870) (max TL $294 \mathrm{~cm}$ ), Carcharhinus falciformis (Bibron, 1839) (max TL $330 \mathrm{~cm}$ ), Carcharhinus galapagensis (Snodgrass \& Heller, 1905) (max TL $370 \mathrm{~cm}$ ), Carcharhinus limbatus (Valenciennes, 1839) (max TL $255 \mathrm{~cm}$ ), Carcharhinus longimanus (Poey, 1861) (max TL $395 \mathrm{~cm}$ ), Carcharhinus perezi (Poey, 1876) (max TL $295 \mathrm{~cm})$, and Carcharhinus signatus (Poey, 1868) (max TL $280 \mathrm{~cm})$.

The work of Curtis (1911) sheds light on a possible explanation for the association of Triloculatum species with larger shark species. Through a series of feeding experiments, Curtis demonstrated that specimens of "Scolex polymorphus" taken from Cynoscion regalis (Bloch \& Schneider, 1801), the weakfish (Sciaenidae) from the Woods Hole region, fed to "sand sharks" (Carcharias littoralis [sic]) at Woods Hole, likely developed into young $T$. triloculatum (as $P$. triloculatum). Cynoscion regalis is a relatively large teleost ( $90 \mathrm{~cm} \mathrm{TL})(\mathrm{Chao}, 2002)$ that is unlikely to be consumed by any but larger, apex predators. Given their association with large sharks, we predict that other Triloculatum species will also be found to have plerocerci that use large teleosts as their final intermediate (or paratenic) hosts.

Their unique possession of subloculi and trifid hooks provides good reason to believe that Phoreiobothrium and Triloculatum are sister taxa. It is interesting, then, that species in these 2 genera tend to co-occur in the same host species. To date, 3 of the 6 shark species that host Triloculatum have also been found to host at least 1 species of Phoreiobothrium (see Caira et al., 2005): Carcharhinus obscurus hosts P. lasium; C. plumbeus hosts $P$. blissorum Caira, Richmond \& Swanson, 2005; and N. acutidens hosts P. perilocrocodilus Caira, Richmond \& Swanson, 2005. We are currently in the process of describing new Phoreiobothrium species, collected over the course of this study, that include 1 from each of C. acronotus, C. brevipinna, and C. isodon. It seems possible that the co-occurrence of members of these 2 genera in the same host species may be the result of a duplication event that occurred relatively early in the evolution of carcharhinid sharks and that was subsequently reflected in the cestode faunas of Carcharhinus and Negaprion species over evolutionary time. However, formal phylogenetic analysis is required to explore this issue further. Of particular interest, in this context, is the relationship between Triloculatum and Phoreiobothrium species hosted by carcharhinid taxa and Phoreiobothrium species hosted by the sister family to the Carcharhinidae, the Sphyrnidae (hammerhead sharks). It is of note that, to date, our work has not revealed members of the genus Triloculatum in hammerheads.

We were able to examine the mode of attachment of T. bullardi to the mucosal surface of the spiral intestine of its host, the spinner shark, Carcharhinus brevipinna (see Figs. 61-62). Like all carcharhinids, this shark possesses a spiral intestine that is of the scroll type (Compagno, 1988). Gross examination of the spiral intestine in this, and other, carcharhinid shark species indicates that the mucosal surface is relatively uniform throughout much of its surface, with the exception of the region in the posterior inner region of the scroll and also in the region opposite the peritoneal outer covering of the scroll. The surfaces of the mucosa in these regions bear much larger ridges and also larger corresponding crypts. Sections of T. bullardi in situ show that it embeds its scolex within the large crypts located between the large ridges in the posterior inner region of the mucosal surface. The difference in size between the ridges and crypts of the posterior inner surface (bottom half of Fig. 63) and the posterior outer surface (top half of Fig. 63) of the scroll is conspicuous. No specimens of $T$. bullardi were found attached to the mucosal surface in regions bearing the smaller ridges and crypts.

Triloculatum appears to have a relatively broad geographic distribution. The species reported here are found in the western Atlantic Ocean from North Carolina to Massachusetts ( $T$. triloculatum,), the Gulf of Mexico (T. bullardi, T. geeceearelensis, T. jodyi, and T. oregontwoae), and the Arafura Sea off northern Australia (T. andersonorum). In addition, the species reported by Caira et al. (2001) occurs in the Gulf of California. We predict that examination of additional large Carcharhinus species, many of which occur throughout the Pacific Basin, the eastern Atlantic Ocean, or both, will substantially extend the known distribution of Triloculatum.

\section{ACKNOWLEDGMENTS}

We are grateful to Richard Mounsey for his assistance with the collection of $N$. acutidens in the Arafura Sea. We thank Jack Casey for inviting us to participate in the NOAA NMFS shark-tagging cruise on the RV Oregon II. We also thank Dr. Nathan Riser for donating his research collection to the LRP at the University of Connecticut and, thus, making some of Linton's material available to us for study. We thank Eric Hoffmeyer (Gulf Coast Research Laboratory) for collections of $C$. isodon from Mississippi and Dana Bethea and Lisa Hollensead (Shark Population Assessment Group, NOAA Fisheries Service Panama City Laboratory) for collections of C. isodon from Florida. We thank Robin Overstreet at the Gulf Coast Research Laboratory for allowing us full use of his laboratory facilities and personnel (NSF PEET award DEB 0529684). This work was supported with funds from NSF PEET award DEB 0118882 to J.N.C. and T. Ruhnke; NSF EPSCoR First Award to K.J.; NSF PBI award DEB 0818696 to J.N.C., T. Littlewood, and J. Mariaux; and NSF PBI award DEB 0818823 to K.J.

\section{LITERATURE CITED}

CAIRA, J. N. 1985. An emendation of the generic diagnosis of Phoreiobothrium Linton, 1889 (Tetraphyllidea: Onchobothriidae) with a detailed description of bothridia and hooks. Canadian Journal of Zoology 63: 1199-1206.

- C. J. Healy, And J. Swanson. 1995. A new species of Phoreiobothrium (Cestoidea: Tetraphyllidea) from the great hammerhead shark Sphyrna mokarran and its implications for the evolution of the onchobothriid scolex. Journal of Parasitology 82: 431-438.

- , K. Jensen, And C. J. Healy. 2001. Interrelationships among tetraphyllidean and lecanicephalidean cestodes. In Interrelationships of the Platyhelminthes, D. T. J. Littlewood and R. Bray (eds.). Taylor and Francis, London, U.K., p. 135-158.

- , C. Richmond, And J. Swanson. 2005. A revision of Phoreiobothrium (Tetraphyllidea: Onchobothriidae) with descriptions of five new species. Journal of Parasitology 91: 1153-1174.

Campbell, R. A. 1975. Tetraphyllidean cestodes from western North Atlantic selachians with descriptions of two new species. Journal of Parasitology 61: 265-270.

Chao, N. L. 2002. Sciaenidae. Croakers (drums). In The living marine resources of the western central Atlantic, vol. 3: Bony fishes part 2 (Opistognathidae to Molidae), sea turtles and marine mammals, K. A. Carpenter (ed.). FAO Species Identification Guide for Fishery Purposes and American Society of Ichthyologists and Herpetologists Special Publication No. 5, Rome, Italy, p. 1583-1653. 
Compagno, L. J. V. 1984. FAO species catalogue. Sharks of the world. An annotated and illustrated catalogue of shark species known to date. Part 2. Carcharhiniformes. FAO Fisheries Synopsis (125) 4: 251-655. 1988. Sharks of the order Carcharhiniformes. Princeton University Press, Princeton, New Jersey, 486 p.

, M. Dando, And S. Fowler. 2005. A field guide to the sharks of the world. HarperCollins Publishers, London, U.K., 368 p.

Curtis, W. C. 1911. The life history of the Scolex polymorphus of the Woods Hole region. Journal of Morphology 22: 819-853.

Euzet, L. 1994. Order Tetraphyllidea Carus, 1863. In Keys to the cestode parasites of vertebrates, L. F. Khalil, A. Jones, and R. A. Bray (eds.). CAB International, Hertfordshire, U.K., p. 149-194.

Linton, E. 1901. Parasites of fishes of the Woods Hole region. U.S. Fish Commission Bulletin for 1899, Washington, D.C., p. 405-492.
1905. Parasites of fishes of Beaufort, North Carolina. Bulletin of the Bureau of Fisheries 24: 321-428.

, 1924. Notes on cestode parasites of sharks and skates. Proceedings of the United States National Museum 64: 1-114.

Perrenoud, W. 1931. Recherches anatomiques et histologiques sur quelques Cestodes de Sélaciens. Revue Suisse de Zoologie 38: 469555.

Rodriguez-Ortiz, B., L. Garcia-Prieto, and G. Perez-Ponce de Leon. 2004. Checklist of the helminth parasites of vertebrates in Costa Rica. Revista de Biología Tropical 52: 1-41.

Watson, D. E., AND T. B. Thorson. 1976. Helminths from elasmobranchs in Central American fresh waters. In Investigations of the ichthyofauna of Nicaraguan lakes, T. B. Thorson (ed.). School of Life Sciences, University of Nebraska-Lincoln, Lincoln, Nebraska, p. 629-640. 